\title{
Systemic Banking Crises Database
}

\section{LUC LAEVEN and FABIÁN VALENCIA*}

The paper presents a comprehensive database on systemic banking crises during 1970-2011. It proposes a methodology to date banking crises based on policy indices, and examines the robustness of this approach. The paper also presents information on the costs and policy responses associated with banking crises. The database on banking crises episodes is further complemented with dates for sovereign debt and currency crises during the same period. The paper contrasts output losses across different crises and finds that sovereign debt crises tend to be more costly than banking crises, and these in turn tend to be more costly than currency crises. The data also point to significant differences in policy responses between advanced and emerging economies. [JEL E50, E60, G20]

IMF Economic Review (2013) 61, 225-270. doi:10.1057/imfer.2013.12

he recent global financial crisis has given rise to the largest wave of banking crises seen since the Great Depression. Unlike previous crises over this period, the recent wave of crises has (thus far) affected mostly advanced economies. The effects of the crises are still lingering and in many cases the crisis is still ongoing. The crisis has triggered renewed interest in the causes and effects of banking crises, and the optimal policy response to such crises.

*Luc Laeven is Deputy Division Chief in the Research Department of the International Monetary Fund and Chaired Professor of Finance at CentER, Tilburg University. Fabián Valencia is an economist in the Research Department of the International Monetary Fund. The authors thank Ashok Bhatia, Luis Brandao, Mali Chivakul, Charalambos Christofides, Stijn Claessens, Luis Cortavarria-Checkley, Enrica Detragiache, Lorenzo Forni, Pierre-Olivier Gourinchas (the Editor), Gary Gorton, Phil de Imus, Yuko Kinoshita, Toshiyuki Miyoshi, Marialuz Moreno Badia, Iva Petrova, Dmitriy Rozhkov, Gonzalo Salinas, and two anonymous referees for comments and suggestions, and Jeanne Verrier and Yangfan Sun for excellent research assistance. The views expressed in this paper do not necessarily represent those of the IMF or IMF Board. 
This paper presents a comprehensive database on systemic banking crises during the period 1970-2011 and some stylized facts associated with these banking crisis episodes. We propose a methodology to date banking crisis episodes based on various policy indices, and examine the robustness of this approach to modifying the thresholds applied to these indices and by comparing our dating methodology with credit and output growth realizations. ${ }^{1}$ The database on banking crises episodes during the period 1970-2011 is further complemented with dates for sovereign debt and currency crises during the same period. In total, we identify 147 banking crises, of which 13 are borderline events, over the period 1970-2011. We also count 211 currency crises and 66 sovereign crises over this period.

In addition to the dating of banking crisis episodes, we also present information on the economic costs and policy responses associated with banking crises for a subset of the 147 episodes identified, allowing for a comparison of the policy mix used to resolve banking crises and an assessment of the real effects of banking crises.

In terms of macroeconomic policy responses, we find that monetary and fiscal policies are used more extensively during banking crises in advanced economies than in emerging and developing economies. One explanation is that advanced economies have better financing options to use countercyclical fiscal policy and generally have more space to use monetary policy. Consistent with the greater reliance on macroeconomic policies in advanced economies, we find that fiscal outlays associated with financial sector interventions (including bank recapitalization with public funds) in advanced economies are about half those in emerging and developing economies, despite relatively larger banking systems in advanced economies.

We find that advanced and emerging economies tend to experience larger output losses than developing economies. These larger output losses are to some extent driven by deeper banking systems, which makes a banking crisis more disruptive (Kroszner, Laeven, and Klingebiel, 2007). Advanced economies also experience statistically significant larger increases in public debt than emerging and developing economies, which may be associated with a greater use of countercyclical fiscal policy. Although expansionary macroeconomic policies indirectly support banks by enhancing their growth prospects, such policies risk slowing down actual bank restructuring, as evidenced by diverging gaps between market and book values of bank equity.

Finally, we compare the output losses across these different types of financial crises and find that sovereign crises generate larger output losses

\footnotetext{
${ }^{1}$ This paper is a more comprehensive and definitive version of two earlier working papers (Laeven and Valencia, 2008, 2012). Compared with these working papers, this paper presents a more detailed discussion of the construction of the banking crisis database, robustness analysis of the methodology used to date banking crisis episodes, and a more comprehensive discussion of the stylized facts associated with banking crises, including their policy responses and real effects.
} 
than banking crises, although the difference is not statistically significant. However, both types of crises in turn generate larger output losses than currency crises. Moreover, output losses associated with twin crises are more severe than those corresponding to standalone crises.

The paper contributes to a large literature on the causes, consequences, and resolution of financial crises, including Kaminsky and Reinhart (1999), Caprio, Klingebiel, Laeven, and Noguera (2005), Laeven and Valencia (2008), Reinhart and Rogoff (2009), Schularick and Taylor (2012), Gourinchas and Obstfeld (2012), and others. Relative to these and other papers, the main value added of our study is the dating of banking crises and the documentation of policy responses during such crises.

The remainder of the paper is organized as follows. Section I presents a comprehensive list of banking crises for the period 1970-2011, including our proposed methodology to date banking crises as well as robustness checks of this methodology. Section II presents the policy responses and outcomes in terms of fiscal costs and real costs during banking crises. Section III presents a comprehensive list of currency and sovereign crises since 1970. Section IV concludes.

\section{Definition of a Banking Crisis}

Dating the start of banking crises is a complex matter because they vary in how they develop. Some crises evolve gradually, gaining speed as the ripple effects from a seemingly small shock propagate forward in time and throughout the economy until the effects reach systemic proportions (as was the case in the recent crisis in the United States). Other episodes happen more abruptly and are often the result of a sudden stop (as was the case in Mexico after the 1994 devaluation of the domestic currency). Outcomes associated with such banking crises may differ substantially as well. Some crises are characterized by the collapse of an important fraction of the banking system (as was the case in Indonesia in the late 1990s), while in other crises, regulatory forbearance and government support keeps most banks alive without leading to significant bank closures (as was the case in Argentina in 2001). Moreover, some banking crises are associated with a collapse in aggregate demand while others can be linked to poor lending decisions and management failures at the bank level.

Identifying crises based on the evolution of credit and bank liabilities is fraught with difficulties as well. The stock of credit may decline with a delay and may decline more slowly than GDP. This may be the case if currency depreciation at the onset of the crisis increases the domestic currency value of foreign-currency-denominated outstanding loans, as in many emerging market crises, or because loans are rolled over and held at book values in banks' balance sheets for several years before they are written off (as was the case with the "zombie" banks during the 1990s crisis in Japan). The evolution of deposits and other bank liabilities may be affected by similar problems, 
and additionally may be sticky in the presence of deposit insurance arrangements or credible government guarantees on bank liabilities.

For these reasons, the dating of banking crises has traditionally relied primarily on the identification of "events" or subjective criteria to determine when a banking crisis takes place (for example, Caprio and Klingebiel, 1996; Caprio, Klingebiel, Laeven, and Noguera, 2005; and Reinhart and Rogoff, 2009). The advantage of such an approach is its flexibility, given the very different manifestations of a banking crisis. The disadvantage is that it may be seen as arbitrary. To make progress toward a definition that is less subject to such criticism, we define a banking crisis as an event that meets two conditions:

(1) Significant signs of financial distress in the banking system (as indicated by significant bank runs, losses in the banking system, and/or bank liquidations).

(2) Significant banking policy intervention measures in response to significant losses in the banking system.

We consider the first year that both criteria are met to be the year when the crisis became systemic. This is to ensure that we date the crisis at the first signs of major problems in the banking system.

The first criterion is a necessary and sufficient condition. It is sufficient because a banking crisis may well result in the collapse of the banking sector without any government intervention. Yet, such cases are very rare, at least over the period we cover. ${ }^{2}$ Relying exclusively on the first criterion, however, is problematic because it is not always straightforward to quantify the degree of financial distress in a banking system. For instance, in advanced economies with well-functioning interbank markets, financial distress may be readily observed in jumps in the volatility of interbank rates. However, in less developed financial markets, shocks to banks' balance sheets, such as those derived from heightened pressures on the currency, may either appear with some delay or be absorbed by offsetting positions at banks. As a result, it is hard to quantify the degree of financial distress in the banking system at a given point in time. Furthermore, bank runs and credit crunches are only partially captured by the evolution of credit and deposit series, as highlighted earlier.

Because there are cases where the first criterion fails to measure financial distress in a timely and precise manner, we add the second criterion on policy interventions as an indirect measure of financial distress. Clearly, policy intervention as captured by the second criterion is not random and follows from perceived distress in the banking sector. Therefore, the second criterion is a sufficient condition for identifying a banking crisis, provided it meets the requirement of being significant, as explained next.

\footnotetext{
${ }^{2}$ One concrete historical example is Latvia's 1995 crisis, when banks totaling 40 percent of financial system's assets were closed, depositors experienced losses, but policy intervention was limited.
} 
We consider policy interventions in the banking sector to be significant if at least three out of the following six measures have been used: ${ }^{3}$

(1) deposit freezes and/or bank holidays

(2) significant bank nationalizations

(3) bank restructuring gross costs (at least 3 percent of GDP)

(4) extensive liquidity support (5 percent of deposits and liabilities to nonresidents)

(5) significant guarantees put in place

(6) significant asset purchases (at least 5 percent of GDP)

In essence, all policy interventions to resolve a banking crisis can be classified into the above six categories (see Honohan and Laeven, 2005, and Laeven and Valencia, 2008). However, not all six are resorted to in all crises, but some are used only when there is a crisis. Deposit freezes and bank holidays have been used only in the context of crises, but are not that common over the time period considered (only a handful of countries used them in our sample and more recently Cyprus). Bank nationalizations and restructuring costs, which involve mostly recapitalizations, are also most likely to occur during a crisis, but not necessarily during a systemically important crisis. Liquidity support and guarantees can be used preemptively without a crisis materializing, as in several countries during the recent wave (Laeven and Valencia, 2010), and asset purchases may also take place in the context of unconventional monetary policy.

To avoid labeling a nonsystemic event or the preemptive use of some of these policies as a systemic banking crisis, we require that at least three measures have been put in place. We chose three policies as our threshold because in several instances, in particular during the recent wave of crises, several countries used both liquidity support and guarantees preemptively. Therefore, a minimum of three measures is needed as a threshold not to label these cases as systemic banking crises. For interventions that can be quantified more easily, such as liquidity support, asset purchases, and financial restructuring costs, we also adopt quantitative thresholds to determine significant intervention. The reason for doing this is to minimize type-I errors in the dating of banking crises because some of these interventions occur during nonsystemic events as well.

There are cases, however, where countries intervened in their financial sectors using a combination of less than three of these measures but did so on a large scale (for example, by nationalizing all major banks in the country). Therefore, we consider a sufficient condition for a crisis episode to be deemed systemic when either (i) a country's banking system exhibits

\footnotetext{
${ }^{3} \mathrm{We}$ express our measure of fiscal costs in terms of GDP rather than the size of a country's financial system to control for the ability of a country's economy to support its financial system. This naturally results in higher measured fiscal costs for economies with larger financial systems. We nevertheless also report, whenever available, fiscal costs expressed in percent of financial system assets.
} 
significant losses resulting in a share of nonperforming loans (NPLs) above 20 percent or bank closures of at least 20 percent of banking system assets or (ii) fiscal restructuring costs of the banking sector are sufficiently high, exceeding 5 percent of GDP.

Additional criteria could in principle be included in our dating approach. However, for consistency purposes it is important to ensure that all cases are judged by the same metric. This implies the requirement to come up with a definition that can be applied over the whole sample period and across a wide array of countries. For instance, relying on stock market data or interbank rates would limit the sample primarily to emerging and advanced economies, because such data are generally not available in less developed economies. Our definition satisfies this requirement.

In implementing this definition of systemic interventions, we consider liquidity support to be extensive when the ratio of central bank claims on the financial sector to deposits and foreign liabilities exceeds 5 percent and more than doubles relative to its precrisis level. ${ }^{4} \mathrm{We}$ also include any liquidity support extended directly by the Treasury. This measure of liquidity captures the impact of currency swap lines among central banks, as the amounts swapped and extended to the financial sector will generally be included in central bank claims on the financial sector. However, it does not include liquidity that subsidiaries of a multinational bank receive in a foreign country. For instance, liquidity provided by the U.S. Federal Reserve to U.S. subsidiaries of Swiss banks would not be measured as liquidity support in Switzerland, but would be included in U.S. liquidity support. However, this limitation has no impact on the identification of systemic crises in our sample. A broader related aspect is that some crises do not originate domestically but are imported from abroad when foreign subsidiaries of domestic banks get in trouble. One concrete example among recent crisis cases is Austria, where most of the problems originated in Austrian banks' foreign subsidiaries.

The policy variables we used in our crisis definition are more specifically defined as follows:

1. Deposit freeze and bank holidays: indicates whether or not the authorities imposed a freeze on deposits or declared a bank holiday. If implemented, we also collect information on the duration of the deposit freeze and bank holiday, and the type of deposits affected.

2. Significant nationalizations: takeovers by the government of systemically important financial institutions and includes cases where the government takes a majority stake in the capital of such financial institutions.

\footnotetext{
${ }^{4}$ We exclude domestic nondeposit liabilities from the denominator of this ratio because information on such liabilities is not readily available on a gross basis. For euro area countries, we also consider liquidity support to be extensive if in a given semester the increase in this ratio is at least 5 percentage points. The reason is that data on euro area central bank claims are confounded by large volumes of settlements and cross-border claims between banks in the Eurosystem. As a result, the central banks of some euro area countries (notably Germany and Luxembourg) had already large precrisis levels of claims on the financial sector.
} 
3. Significant bank guarantees: a significant government guarantee on bank liabilities, indicating that either a full protection of liabilities has been issued by the government or that government guarantees have been extended to nondeposit liabilities of banks. ${ }^{5}$ Actions that only raise the level of deposit insurance coverage are not included. We also collect information on whether or not a previous explicit deposit insurance arrangement was in place at the time of the introduction of the blanket guarantee.

4. Liquidity support: indicates liquidity support from the central bank, measured as the ratio of central bank claims on deposit money banks (line 12 in IFS) and liquidity support from the Treasury to total deposits and liabilities to nonresidents. Total deposits are computed as the sum of demand deposits (line 24), other deposits (line 25), and liabilities to nonresidents (line 26). We report two measures, the peak and the change between the peak and precrisis levels.

5. Bank restructuring costs: defined as gross fiscal outlays directed to the restructuring of the financial sector, with the most important component being recapitalization costs. We exclude liquidity assistance from the Treasury because we include this in our measure of liquidity support. We consider restructuring costs to be significant if they exceed 3 percent of GDP. We base our definition on gross fiscal costs instead of net because the gross amount reflects the intensity of the intervention. However, wherever data on recoveries were available we report also net fiscal costs.

6. Asset purchases: It includes asset purchases from financial institutions implemented by the central bank, the Treasury, or a government entity (such as an asset management company). We define significant asset purchases as those exceeding 5 percent of GDP. ${ }^{6}$

\section{Ongoing Banking Crises}

To examine how small changes to our definition affect the list of crises episodes, we also create an additional list of "borderline cases," corresponding to cases where our definition of a systemic crisis is almost met. Table 1 provides the list of countries that meet our definition during the recent episode as well as the borderline cases. The table indicates that lowering our requirement to only two (instead of three) policy interventions would increase the number of systemic crises by 8 during the recent wave of crises. ${ }^{7}$ To generate significant

\footnotetext{
${ }^{5}$ Although we do not consider a quantitative threshold for this criteria, in all cases guarantees involved significant financial sector commitments relative to the size of the corresponding economies.

${ }^{6}$ Asset purchases also provide liquidity to the system. Therefore, an estimate of total liquidity injected would include schemes such as the Special Liquidity Scheme (185 billion pounds sterling) in the United Kingdom and Norway's Bond Exchange Scheme (230 billion kronas), as well as liquidity provided directly by the Treasury.

${ }^{7}$ For crises before 2007, the list of borderline cases is also small and includes Brazil 1990, Argentina 1995, Czech Republic 1996, Philippines 1997, and United States 1988.
} 
Table 1. Systemic Banking Crises, 2007-2011

\begin{tabular}{|c|c|c|c|c|c|c|c|}
\hline Country & $\begin{array}{l}\text { Start } \\
\text { of } \\
\text { Crisis }\end{array}$ & $\begin{array}{c}\text { Date } \\
\text { when } \\
\text { Systemic }\end{array}$ & $\begin{array}{l}\text { Extensive } \\
\text { Liquidity } \\
\text { Support }\end{array}$ & $\begin{array}{c}\text { Significant } \\
\text { Guarantees } \\
\text { on } \\
\text { Liabilities }\end{array}$ & $\begin{array}{c}\text { Significant } \\
\text { Restructuring } \\
\text { Costs }\end{array}$ & $\begin{array}{l}\text { Significant } \\
\text { Asset } \\
\text { Purchases }\end{array}$ & $\begin{array}{c}\text { Significant } \\
\text { Nationalizations }\end{array}$ \\
\hline \multicolumn{8}{|c|}{ Systemic cases } \\
\hline Austria & 2008 & 2008 & レ & $\boldsymbol{\nu}$ & レ & & レ \\
\hline Belgium & 2008 & 2008 & レ & レ & レ & & レ \\
\hline Denmark & 2008 & 2009 & $\nu$ & $\boldsymbol{\nu}$ & & & $\nu$ \\
\hline Germany & 2008 & 2009 & $\nu$ & $\nu$ & & & $\boldsymbol{\nu}$ \\
\hline Greece & 2008 & 2009 & レ & $\nu$ & $\boldsymbol{\nu}$ & & \\
\hline Iceland & 2008 & 2008 & レ & レ & レ & & レ \\
\hline Ireland & 2008 & 2009 & レ & レ & レ & レ & レ \\
\hline Kazakhstan & 2008 & 2010 & $\nu$ & & レ & & レ \\
\hline Latvia & 2008 & 2008 & レ & レ & & & レ \\
\hline Luxembourg & 2008 & 2008 & レ & $\boldsymbol{}$ & レ & & レ \\
\hline Mongolia & 2008 & 2009 & $\swarrow$ & 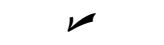 & $\swarrow$ & & $\nu$ \\
\hline Netherlands & 2008 & 2008 & $\boldsymbol{}$ & $\boldsymbol{}$ & レ & & レ \\
\hline Nigeria & 2009 & 2011 & レ & レ & レ & レ & レ \\
\hline Spain & 2008 & 2011 & $\nu$ & $\boldsymbol{\nu}$ & $\nu$ & & \\
\hline Ukraine & 2008 & 2009 & レ & & レ & & レ \\
\hline $\begin{array}{l}\text { United } \\
\quad \text { Kingdom }\end{array}$ & 2007 & 2008 & $\boldsymbol{}$ & $\boldsymbol{\nu}$ & $\boldsymbol{\nu}$ & $\boldsymbol{}$ & $\boldsymbol{}$ \\
\hline $\begin{array}{l}\text { United } \\
\text { States }\end{array}$ & 2007 & 2008 & レ & $\boldsymbol{\nu}$ & レ & $\boldsymbol{\nu}$ & $\boldsymbol{\nu}$ \\
\hline \multicolumn{8}{|c|}{ Borderline cases } \\
\hline France & 2008 & & レ & $\boldsymbol{V}$ & & & \\
\hline Hungary & 2008 & & レ & レ & & & \\
\hline Italy & 2008 & & レ & レ & & & \\
\hline Portugal & 2008 & & レ & レ & & & \\
\hline Russia & 2008 & & レ & レ & & & \\
\hline Slovenia & 2008 & & $\boldsymbol{\nu}$ & $\boldsymbol{}$ & & & \\
\hline Sweden & 2008 & & $\boldsymbol{}$ & $\boldsymbol{}$ & & & \\
\hline Switzerland & 2008 & & $\boldsymbol{}$ & & & レ & \\
\hline
\end{tabular}

Source: Authors' calculations.

Notes: Systemic banking crises are defined as cases where at least three of the listed interventions took place, whereas borderline cases are those that almost met our definition of a systemic crisis. Extensive liquidity support is defined as a situation where the amount of central bank claims on the financial sector and liquidity support from the Treasury exceeds 5 percent of deposits and foreign liabilities and is at least twice as large as precrisis levels; direct bank restructuring costs are considered significant when they exceed 3 percent of GDP and exclude liquidity and asset purchase outlays; guarantees on liabilities are considered significant when they include actions that guarantee liabilities of financial institutions other than just increasing deposit insurance coverage limits; nationalizations are significant when they affect systemic financial institutions.

further changes to the list of crises, a much more drastic relaxation of our definition would be required. Table 1 shows for each case the exact criteria that are met. We do not include a separate column for deposit freezes and bank holidays because no episode during this recent wave of banking crises made 
use of banking holidays, while deposit freezes were used only for Parex bank in Latvia. ${ }^{8}$ In total, we identify 13 systemic banking crises and 8 borderline cases since the year 2007. Cyprus, which meets our banking crisis definition starting in 2012, is not included in our sample which ends in 2011. Table A1 presents more detailed information about the policy interventions in these cases.

For each crisis, we report the date when the crisis started, corresponding to the first signs of significant distress, as well as the date when the crisis became systemic, which we define as the date when our definition of a systemic crisis was first met.

The starting dates for the recent crises are as follows: the United States and the United Kingdom start in 2007, Nigeria in 2009, and all the other cases in 2008. In each of these cases, banking systems showed significant signs of distress followed by government intervention during the starting year of the crisis. However, the crisis reached systemic proportions according to our definition only in 2009 in Denmark, Germany, Greece, Ireland, Mongolia, and Ukraine, in 2010 in Kazakhstan, and in 2011 in Nigeria and Spain. For some of these countries, however, the dates would alter slightly if our thresholds are relaxed. For instance, Spain crosses our 3 percent threshold for bank restructuring costs in 2011. If we were to reduce this threshold to 1 percent, then Spain's crisis would be labeled as systemic starting already in 2009. However, such changes are rare in our sample. This is primarily because the requirement that three policies be in place reduces the sensitivity of our dating to the use of these quantitative thresholds. For instance, Germany does not cross our significant bank restructuring costs threshold of 3 percent of GDP, but even if we were to choose a much lower threshold, the dating for Germany would not change. This is the case because it already qualifies as a systemic crisis given that a sufficient number of other policies have been put in place. Of course, the sample of crises would increase more substantially if we were to lower the three thresholds all at once.

To validate our crisis dating more systematically, we conduct the following experiment: We construct an alternative definition of a crisis that corresponds to the first year before two conditions are simultaneously met: negative real GDP growth and a slowdown in nominal credit growth (IFS line 22d). The rationale for this alternative definition is straightforward. Banking crises disrupt the supply of credit (Bernanke and Gertler, 1987, Van Den Heuvel, 2006, Valencia, forthcoming, and others) and these disruptions to the supply of credit can have important real effects because some borrowers cannot substitute bank loans with alternative funding sources (Peek and Rosengren, 1997; Ashcraft, 2005; Laeven and Valencia, 2013, and others). In essence, by looking at declines in credit growth in conjunction with negative GDP growth, we look for evidence of the two main implications

\footnotetext{
${ }^{8}$ Cyprus, which imposed deposit freezes and capital controls in 2013, is not included in our sample, which covers banking crises up to 2011.
} 
Table 2. Robustness of Crisis Dates

\begin{tabular}{llll}
\hline Alternative methodology & & & \\
\hline Our dating & 0 & 1 & Total \\
0 & 4,296 & 545 & 4,841 \\
1 & 85 & 62 & 147 \\
Total & 4,381 & 607 & 4,988 \\
\hline
\end{tabular}

Note: $1=$ crisis based on the corresponding criteria.

The alternative methodology assigns a value of 1 to the year before two conditions are met: real GDP growth is negative and nominal credit growth is lower than the year before.

of banking crises. We use nominal credit growth rather than the level of credit because the stock of outstanding loans measured in domestic currency need not decline during crisis times even if there is no new lending. This is the case because of exchange rate valuation effects or because preexisting credit lines are drawn upon.

Table 2 compares our dating with what would result from the simple alternative methodology discussed above based on observed realizations of negative real GDP growth and a slowdown in nominal credit growth. Out of the 147 episodes we report in this paper, in 62 episodes or in 42 percent of cases, our crisis dates coincide with a decline in real GDP and a slowdown in credit growth. But many of the cases for which we obtain conflicting results are developing countries where the reliability of the data is an issue. When we split our sample according to income level, the matching is much better for advanced and emerging economies, especially for advanced economies where our crisis dates coincide with the dates generated based on the alternative approach in 18 out of 24 (or 75 percent) of cases (Table 3 ).

To illustrate graphically how this alternative methodology compares to our dating approach, Figure 1 shows the evolution of real GDP growth and nominal credit growth for a selected number of crises. Our dating method coincides precisely with the outcome of the alternative methodology in each of these crises. And although the alternative methodology often points to the occurrence of multiple crises following the start of the crisis according to our dating approach, such "false positives" typically correspond to the same crisis episode as indicated by our dating approach.

Our dataset also includes the corresponding month for the reported dates as well as the month when liquidity support peaked, allowing for an analysis of banking crises at a monthly frequency. ${ }^{9}$ Figure 2 depicts the frequency of banking crises by month of all banking crises since the 1970s. An interesting pattern emerges: banking crises tend to start in the second half

\footnotetext{
${ }^{9}$ Monthly crisis dates (including the start of the crisis, the date when the crisis became systemic, and the date when liquidity support peaked) can be found in the companion data file to this paper.
} 
Table 3. Robustness of Crisis Dates by Income Level

\begin{tabular}{llll}
\hline Income level: Developing alternative methodology & & \\
Our dating & 0 & 1 & Total \\
0 & 1,419 & 208 & 1,627 \\
1 & 34 & 11 & 45 \\
Total & 1,453 & 219 & 1,672 \\
\multicolumn{1}{l}{ Income level: Emerging alternative methodology } & & \\
Our dating & 0 & 1 & Total \\
0 & 2,059 & 334 & 2,393 \\
1 & 44 & 34 & 78 \\
Total & 2,308 & 272 & 2,471 \\
& & & \\
Income level: Advanced alternative methodology & 0 & 1 & Total \\
Our dating & 852 & 141 & 993 \\
0 & 6 & 18 & 24 \\
1 & 858 & 159 & 1,017 \\
Total & & & \\
\hline
\end{tabular}

Note: $1=$ crisis based on the corresponding criteria.

The alternative methodology assigns a value of 1 to the year before two conditions are met: real GDP growth is negative and nominal credit growth is lower than the year before.

of the year, with large September and December effects. However, the September effect is primarily driven by the 2008 crisis wave, around the time of the Lehman Brothers bankruptcy.

Banking crises are a worldwide phenomenon. Figure 3 shows the regional distribution of crises, highlighting countries that experienced multiple systemic banking crises during 1970-2011. Many countries experienced more than one crisis over this period, but only two countries, Argentina and the Democratic Republic of Congo, experienced more than two systemic banking crises.

In total, we count 147 banking crises since 1970, of which 13 are borderline events, including those reported in Table 1. The complete dataset is available from the Palgrave website at www.palgrave-journals.com/imfer.

\section{Banking Crisis Cycles}

Consistent with earlier work (for example, Reinhart and Rogoff, 2009), we find that crises occur in waves. Figure 4 presents the number of banking crises that start in a given year, showing a marked pickup in crisis activity in the early 1980s. During the 1990s, there were three clusters of crises in the transition economies, in Latin America during the Tequila crisis, and in East Asia during the Asian financial crisis. The early 2000s were a relatively calm period, but ended with the most recent wave, consisting of the largest number of crises since 1970. These crisis cycles frequently 
Figure 1. Alternative Dating Methodology for Selected Crises
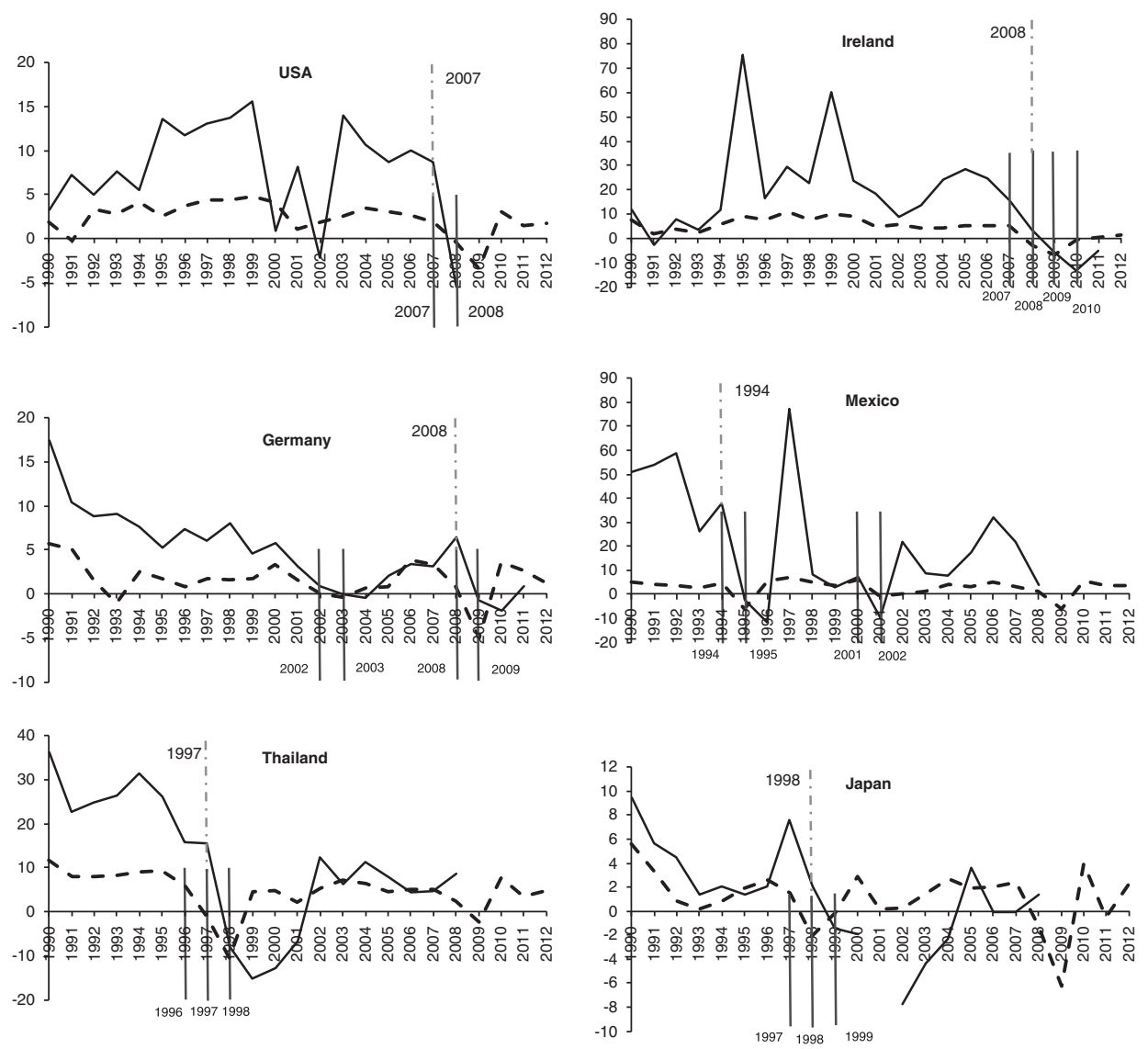

_ - Growth Rate of GDP — Growth Rate of Credit

- - Growth Rate of GDP — Growth Rate of Credit

Notes: Solid vertical lines denote the year before two conditions are met: negative real GDP growth and a slowdown in nominal credit growth (that is, crisis dates per the alternative dating methodology). Dashed vertical lines denote the start of the banking crisis per our dating methodology.

coincide with credit cycles. Out of 129 banking crisis episodes for which credit data are available, 45 episodes (or about one in three) were preceded by a credit boom. ${ }^{10}$

${ }^{10}$ Following Dell'Ariccia and others (2012), we define credit boom years as those during which the deviation of credit-to-GDP ratio relative to its trend is greater than 1.5 times its historical standard deviation and its annual growth rate exceeds 10 percent, or years during which the annual growth rate of the credit-to-GDP ratio exceeds 20 percent. A countryspecific cubic trend is computed over the preceding 10-year period. 
Figure 2. Frequency of Starting Month of Banking Crises

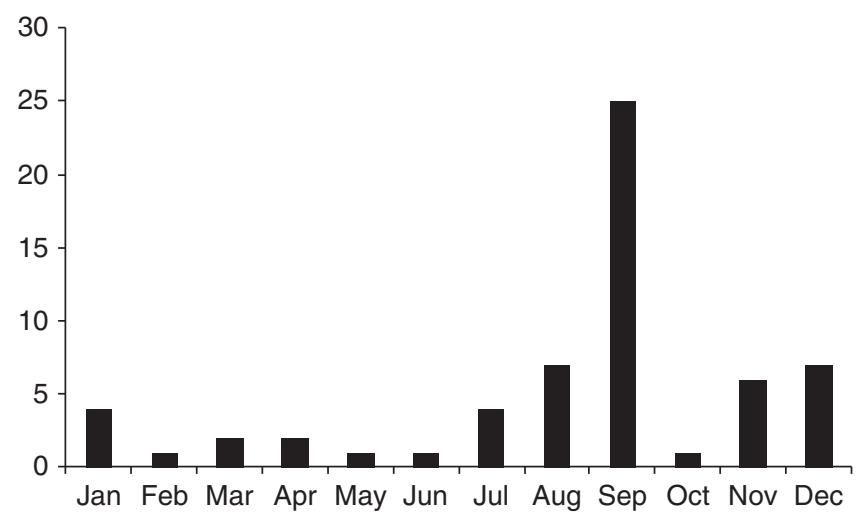

Source: Authors' calculations.

Figure 3. Frequency of Systemic Banking Crises Around the World, 1970-2011

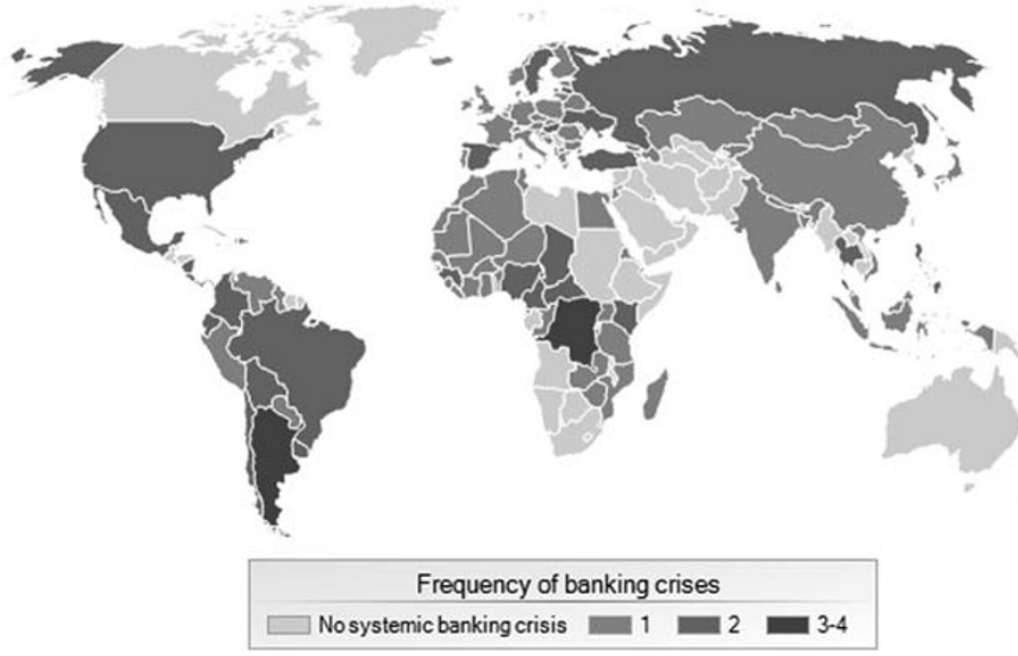

Source: Authors' calculations.

\section{Policy Responses and Outcomes in Banking Crises}

We now examine how countries coped with the banking crises we have identified through our methodology. At the same time, we collect information on outcomes of banking crises. We contrast policy responses and outcomes across countries at different income levels. ${ }^{11}$ In doing so, we

${ }^{11}$ Alternatively, Laeven and Valencia (2010) and Claessens and others (2011) perform comparisons between past and recent crises. 
Figure 4. Banking Crises Cycles

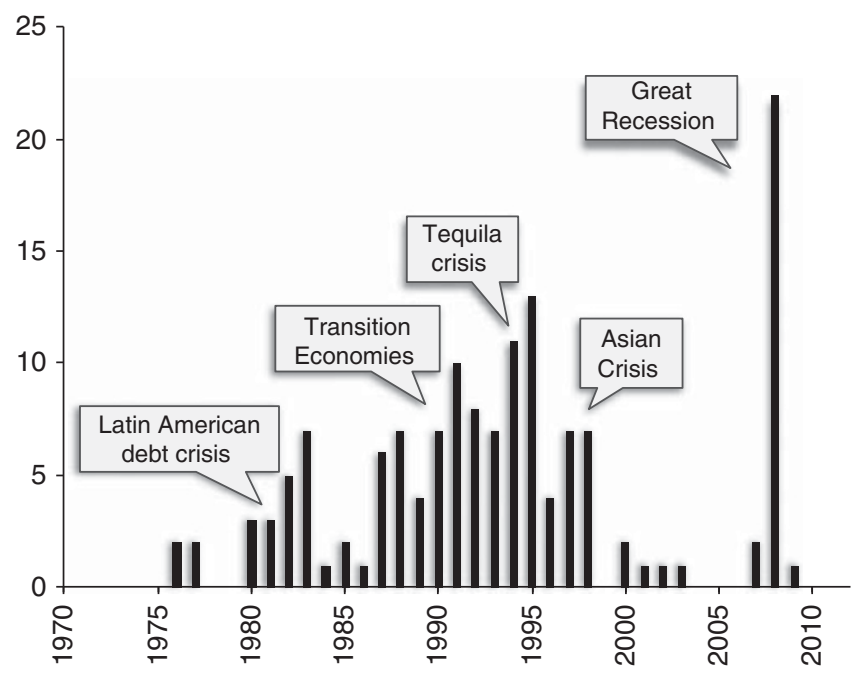

Source: Authors' calculations.

Notes: Number of systemic banking crises starting in a given year.

collect information on financial policies such as liquidity support, guarantees, bank recapitalization with public funds, as well as measures of monetary and fiscal policy. Outcomes are measured in terms of fiscal costs, increases in public debt, output losses, and NPLs. ${ }^{12}$

\section{Policy Response}

Initially, a country's policy options are limited to those policies that do not rely on the formation of new institutions or complex new mechanisms. Immediate policy responses include (a) suspension of convertibility of deposits, which prevents bank depositors from seeking repayment from banks, (b) regulatory forbearance, ${ }^{13}$ which allows banks to avoid the cost of regulatory compliance (for example by allowing banks to overstate their equity capital in order to avoid the costs of contractions in loan supply), (c) emergency liquidity support to banks, or (d) a government guarantee of depositors. Each of these immediate policy actions are motivated by adverse changes in the condition of banks.

Banks suffering severe losses tend not only to see rising costs but also to experience liability rationing, either because they must contract deposits to satisfy their regulatory capital requirement, or because depositors at risk of

\footnotetext{
${ }^{12}$ Comparisons based on NPL data should be interpreted with caution given that definitions of NPLs vary markedly across countries.

${ }^{13}$ Regulatory forbearance often continues into the resolution phase, though it is generally viewed as a crisis containment policy.
} 
loss prefer to place funds in more stable intermediaries or markets. Banks, in turn, will transmit those difficulties to their borrowers in the form of a contraction in the supply of credit. Credit will become more costly and financial distress of borrowers and banks more likely.

Optimal policy design requires knowing the nature of the problems, whether the trigger for the crisis is a loss of depositor confidence (triggering a deposit run) and thus it is only a liquidity crisis, or if it is a bank insolvency problem, or the knock-on effects of financial asset market disturbances outside the banking system, including exchange rate and wider macroeconomic pressures.

Deposit withdrawals can be addressed by emergency liquidity loans, usually from the central bank when market sources are insufficient, by an extension of government guarantees of depositors and other bank creditors, or by a temporary suspension of depositor rights in what is often called a "bank holiday" or freezing of deposits. Each of these techniques is designed to buy time. The success of each technique will crucially depend on the credibility and creditworthiness of the government.

Preventing looting of an insolvent or near insolvent bank requires a different set of containment tools. These may include administrative intervention including the temporary assumption of management powers by a regulatory official, or closure, which may for example include the subsidized compulsory sale of a bank's good assets to a sound bank. This may come together with the assumption by the acquiring bank of all or most of the failed entity's banking liabilities; or more simply an assisted merger. Here the prior availability of the necessary legal powers is critical, given the incentive for bank insiders to hang on, as well as the customary cognitive gaps causing insiders to deny the failure of their bank.

Most complex of all are the cases where disruption of banking is part of a wider financial and macroeconomic turbulence. In this case, the bankers may be innocent victims of external circumstances, and it is now that special care is needed to ensure that regulations do not become part of the problem. Regulatory forbearance on capital and liquid reserve requirements may prove to be appropriate in these conditions. Regulatory forbearance allows banks to avoid the cost of regulatory compliance, for example, by allowing banks to overstate their equity capital in order to avoid costly contractions in loan supply.

Once containment measures have been put in place, governments face the long-run challenge of restoring solvency in the banking sector. Because raising capital on their own is difficult during times of distress, there is a case for public recapitalizations, which have been shown theoretically to increase welfare (Philippon and Schnabl, 2013, Sandri and Valencia, forthcoming, and others) and empirically to increase growth (Giannetti and Simonov, 2013, Laeven and Valencia, 2013 and others). Implementation, however, may take many forms (Laeven and Valencia, 2008).

The differences in policy mix between advanced economies and emerging economies is summarized in Figure 5. The figure shows the fraction of 
Figure 5. Differences in the Mix of Crisis Policies

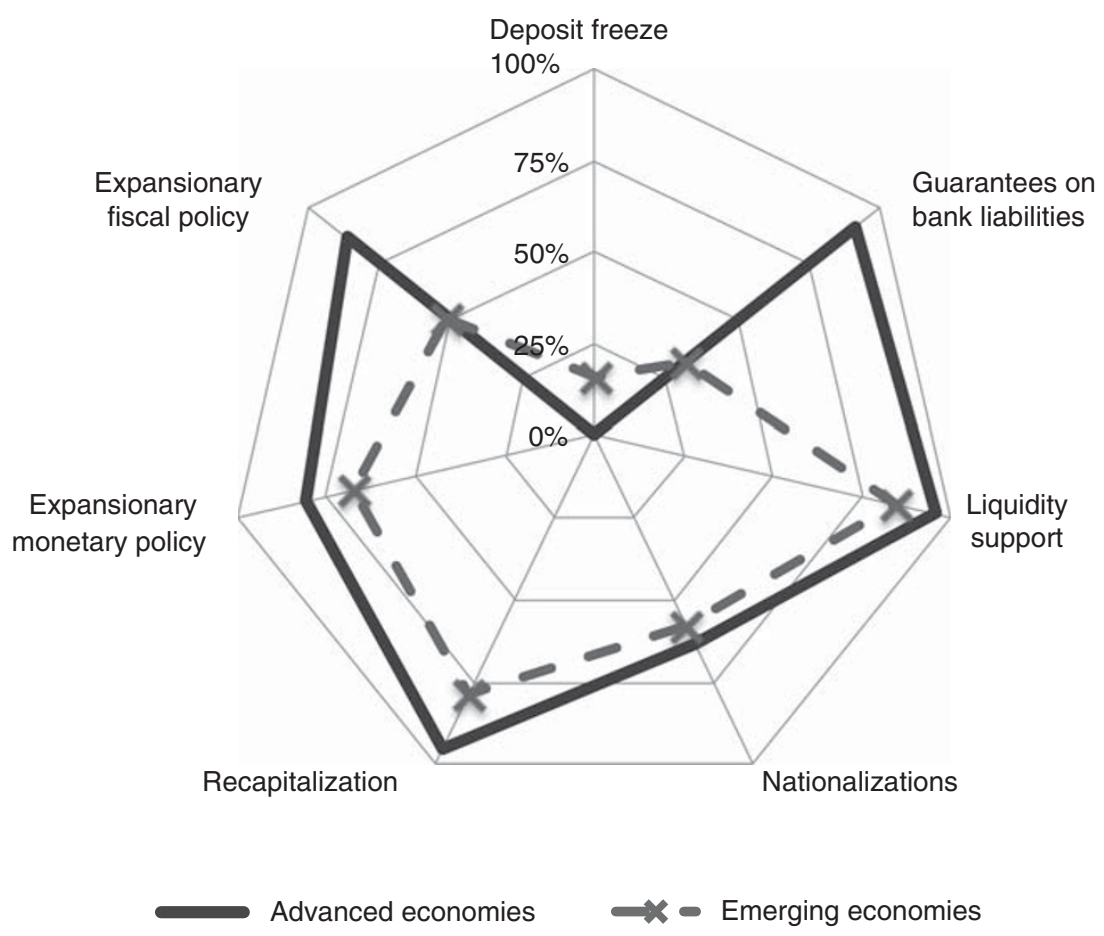

Source: Authors' calculations.

episodes in which the corresponding policy was used, differentiating countries by income level.

Deposit freezes, while rare, are most frequently used by emerging economies, whereas guarantees on bank liabilities are more common among advanced economies. Guarantees are more common among advanced economies, perhaps because of generally better institutions and access to international capital markets, rendering the announcement of guarantees more credible. However, as noted in Claessens and others (2011), guarantees during crises in advanced economies were on average less comprehensive (more targeted) than in emerging and developing economies, where they generally covered a broad set of liabilities and were mostly announced in the form of blanket guarantees.

We collect data on whether deposit insurance was in place at the start of the crisis for about half the crises episodes. In 70 percent of episodes for which we collected data, a deposit insurance scheme was already in place when the crisis erupted. Moreover, the data show that emerging economies are more likely to adopt deposit insurance around the time of a crisis. Losses are imposed on bank creditors only in 40 percent of cases, suggesting that implicit guarantees are important. Recapitalization packages and extensive 
liquidity support are also more common in advanced economies, albeit only marginally, whereas nationalizations of financial institutions are equally common in advanced and other economies.

To gain insights into the relative use of fiscal and monetary policy, we construct measures of expansionary fiscal and monetary policies (reported in our data set as monetary and fiscal policy indices) that take a value of one if the policies are expansionary, and zero otherwise. We first construct a variable equal to the difference between the increase in public debt (reported in Table 2) and the fiscal cost of bank intervention policies. The median for this variable is close to 7 percent. This means public debt, after subtracting increases in public debt that can be attributed to financial intervention packages, increases by about 7 percent for the median country. We use this difference as a proxy for the magnitude of discretionary fiscal policies as well as automatic stabilizers. It is admittedly a crude measure, but it should provide a broad indication of the intensity of factors other than bank recapitalization that affected the fiscal position of a country, including discretionary fiscal policy.

For the purpose of the chart, we consider fiscal policy to be expansionary when this variable takes on a value that exceeds its mean by half a standard deviation. Similarly, we define expansionary monetary policy as instances when the increase in reserve money is half a standard deviation above its mean. Figure 5 shows that both expansionary monetary and fiscal policies were more commonly used in advanced economies. The difference, however, is much more pronounced in the case of fiscal policy. Because advanced economies have better access to financing large fiscal deficits, they are in a better position than other economies to allow for fiscal automatic stabilizers to operate during banking crises or even to enact countercyclical discretionary fiscal packages.

\section{Outcomes}

We measure outcomes of the crises with four main variables: the fiscal costs of a crisis (computed as the direct fiscal outlays due to financial sector rescue packages), the output losses (computed as the cumulative loss in income relative to a precrisis trend), the increase in public debt, and the peak in NPLs. Direct fiscal costs include fiscal outlays committed to the financial sector from the start of the crisis up to end-2011. ${ }^{14}$ The increase in public debt is measured in percent of GDP over $[T-1, T+3]$, where $T$ is the starting year of the crisis. ${ }^{15}$

\footnotetext{
${ }^{14}$ To compute fiscal costs we take the figures in domestic currency and divide by the nominal GDP of the corresponding year when the outlays took place. For Greece, we include the recapitalization package included in the 2012 IMF program, although it had not been fully used as of May 2013.

${ }^{15} \mathrm{We}$ approximate the increase in public debt by computing the difference between preand postcrisis debt projections. For crises starting in 2007 or later, we use as precrisis debt figures the debt projections reported in the World Economic Outlook (WEO) issued in the fall
} 
Output losses are computed as deviations of actual GDP from its trend. $^{16}$

Figure 6 offers an illustration of our methodology for a selected group of crises where the shaded area reflects the output loss estimate. It is important to note that our measure of output losses is not a perfect measure of the inefficiency in the level of output arising from the banking crisis. Since the loss is computed from a statistical calculation of trend output, this trend may not necessarily reflect the efficient level of output. It may well be that the efficient level of output declines during the crisis. However, we do not infer a causal link when interpreting these output losses. In other words, these are not necessarily output losses arising exclusively because of a banking crisis, but output losses occurring around banking crises. In addition, it may be the case that output before the crisis was unsustainably high, possibly overstating trend output. This concern is mitigated by the long time horizon of 20 years we use to compute this trend, which is substantially above the standard length of a business cycle. That said, when we include the crisis period observations up to $T+3$ to compute the trend, where $T$ is the start of the crisis, there is an important level effect. The size of the output losses decreases to about a fourth of the reported numbers. However, the ranking does not change materially, and the qualitative nature of the results reported later in Table 4 remains unaltered. Indeed, the correlation between this series of output losses and the one under our baseline methodology is around 90 percent. This implies that while the estimated size of output losses needs to be interpreted with caution, these estimates robustly capture the relative size and heterogeneity of the output losses associated with banking crises.

Table 4 shows the median values for the outcome variables across all episodes reported in our database, over 1970-2011. Table A1 shows individual country-level data. The episodes are classified according to the country's income level (advanced, emerging, or developing economy) at the time of the crisis. In addition to the outcome variables listed above, Table 4 also reports quantitative measures on policy intervention, which complements the frequency of tools used described in the previous section.

of the year before the crisis and the fall 2011 WEO for the postcrisis debt figures. For past episodes, we simply report the actual change in debt. Our choice of data sources is guided by the availability of data on general government debt. When such data are not available, we use data on central government debt instead. Our primary data source is Abbas and others (2010) for crisis episodes prior to 2007 and the fall 2011 WEO for crisis episodes since 2007. When debt data are not available in Abbas and others (2010), we use the OECD Analytical Database and IMF's Government Finance Statistics.

${ }^{16}$ Output losses are computed as the cumulative sum of the differences between actual and trend real GDP over the period [ $T, T+3]$, expressed as a percentage of trend real GDP, with $T$ the starting year of the crisis. Trend real GDP is computed by applying an HP filter (with $\lambda=100$ ) to the log of real GDP series over $[T-20, T-1]$ (or shorter if data are not available, though we require at least four precrisis observations). Real GDP is extrapolated using the trend growth rate over the same period. Real GDP data are from the fall 2011 WEO. This methodology is somewhat different than the one used in Laeven and Valencia (2008), which explains why the numbers changed. 
Figure 6. Output Losses for Selected Crises Episodes
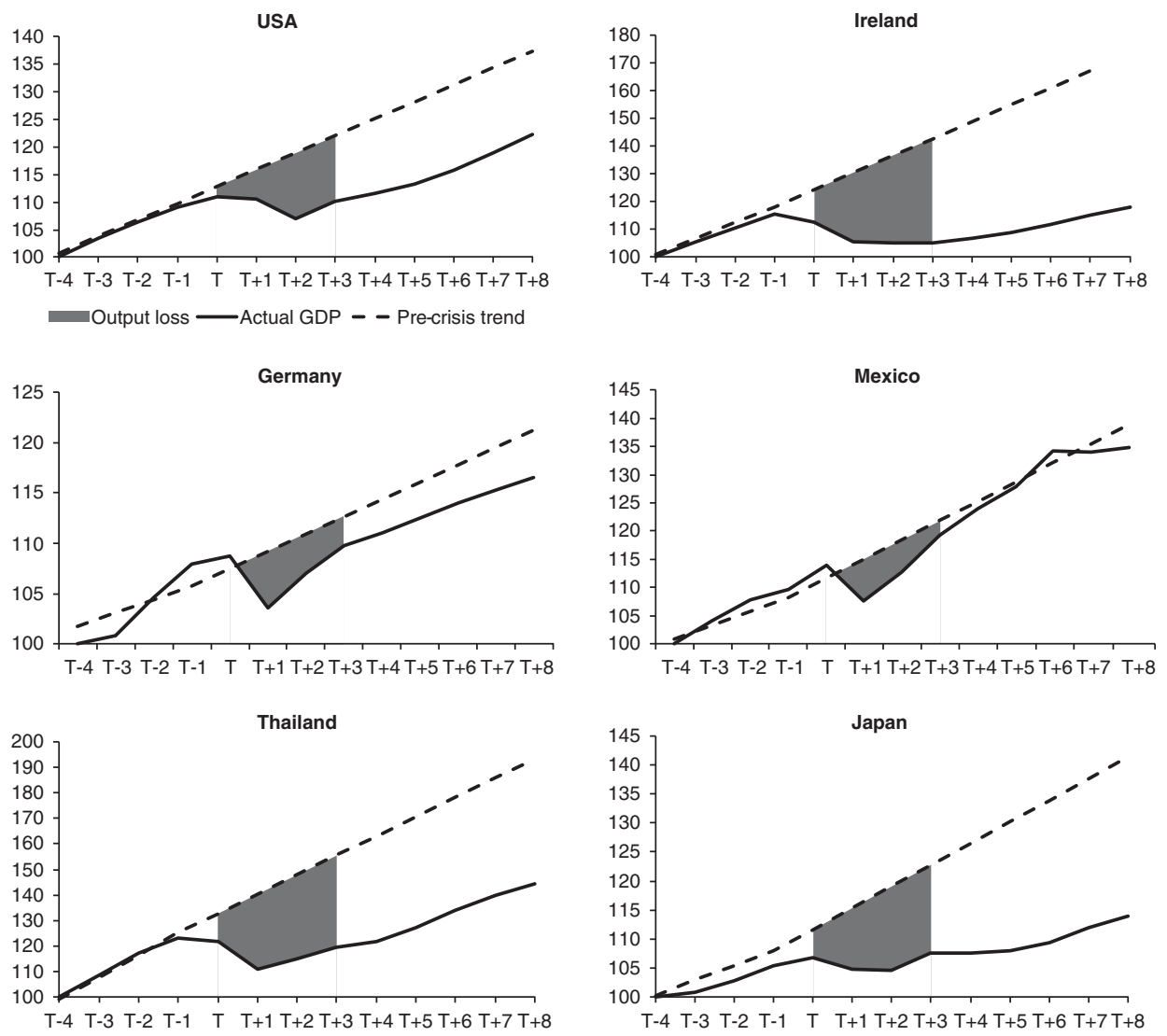

Sources: World Economic Outlook and authors' calculations.

Notes: Year $T$ equals 2007 for the United States, 2008 for Ireland and Germany, 1994 for Mexico, 1997 for Thailand and Japan. GDP in $T-4$ is set equal to 100 .

We report peak liquidity support provided by central banks measured as the highest level of central bank claims against financial institutions, ${ }^{17}$ normalized by the sum of financial institutions' deposits and foreign liabilities. The difference between this peak and the precrisis level of central bank claims is reported as liquidity support provided during the crisis. We also report the duration of the crisis, computed as the difference between the end and start years of the crisis, measured in years. Finally, we

\footnotetext{
${ }^{17}$ Liquidity support is computed as the ratio of central bank claims on deposit money banks (line 12 in IFS) to total deposits and liabilities to nonresidents. The denominator is computed as the sum of demand deposits (line 24), other deposits (line 25), and liabilities to nonresidents (line 26). In the case of euro area economies, central bank claims on deposit money banks include Emergency Liquidity Assistance (ELA) operations conducted by national central banks within the Eurosystem.
} 
Table 4. Banking Crises Outcomes, 1970-2011

\begin{tabular}{|c|c|c|c|c|c|c|c|c|c|}
\hline \multirow[b]{3}{*}{ Country } & Output Loss & Increase in Debt & Monetary Expansion & Fiscal Costs & Fiscal Costs & Duration & Peak Liquidity & Liquidity Support & Peak NPLs \\
\hline & \multicolumn{9}{|c|}{ Medians } \\
\hline & \multicolumn{4}{|c|}{ In percent of GDP } & $\begin{array}{l}\text { In percent } \\
\text { of financial } \\
\text { system assets }\end{array}$ & $\begin{array}{c}\text { In } \\
\text { years }\end{array}$ & \multicolumn{2}{|c|}{$\begin{array}{c}\text { In percent of } \\
\text { deposits and } \\
\text { foreign liabilities }\end{array}$} & $\begin{array}{l}\text { In percent } \\
\text { of total } \\
\text { loans }\end{array}$ \\
\hline All & 23.2 & 12.1 & 1.7 & 6.8 & 12.5 & 4.0 & 20.1 & 9.6 & 25.0 \\
\hline Advanced & 32.4 & 23.6 & 8.3 & 4.2 & 2.1 & 5.0 & 11.6 & 6.0 & 5.0 \\
\hline Emerging & 33.6 & $9.1^{1}$ & $1.3^{1}$ & 8.3 & $21.3^{1}$ & $3.0^{1}$ & $22.2^{1}$ & 10.3 & $29.5^{1}$ \\
\hline Developing & $0.7^{2,3}$ & $10.9^{2}$ & $1.1^{2}$ & 10.0 & $18.3^{2}$ & $2.0^{2}$ & 22.6 & 11.7 & $35.0^{2,3}$ \\
\hline
\end{tabular}

Source: Authors' calculations.

${ }^{1}$ Median value for emerging economies is significantly different than for advanced economies at the 5 percent level, based on a Pearson's chi-squared median comparison test.

${ }^{2}$ Median value for developing economies is significantly different than for advanced economies at the 5 percent level, based on a Pearson's chi-squared median comparison test.

${ }^{3}$ Median value for developing economies is significantly different than for emerging economies at the 5 percent level, based on a Pearson's chi-squared median comparison test. 
report data on the monetary expansion computed as the change in the monetary base between its peak during the crisis and its level one year prior to the crisis, expressed in percentage points of GDP. ${ }^{18}$

We also report end dates for each crisis, except for recent crises where our condition for determining the end of a crisis is not (yet) met. ${ }^{19}$ We also report the peak level of NPLs, over the period $[T, T+5]$, where $T$ is the starting year of the crisis. For the recent episodes, where a five-year window may not be available yet, the peak is computed over the period [ $T$, latest data available]. These outcome variables are constructed for illustrative purposes to gauge the outcomes around banking crises. It is important to note that they reflect the total impact of the crisis, including any feedback effects and other factors contemporaneous to the banking crisis. Therefore, just as we discussed it in the context of output losses, these outcomes should not be attributed to the banking crisis alone.

The median output loss for emerging and advanced economies is not statistically different from each other, but both are statistically significantly larger than that in developing countries. Increases in public debt tend to be larger in advanced economies than in emerging and developing economies (although the difference between emerging and developing economies is not statistically significant). Output losses in advanced and emerging economies are larger in part because with deeper financial systems, a banking crisis is more disruptive. Moreover, for the crises that started in 2007 onward, the median output loss reaches 25 percent, whereas the noncrisis countries exhibit a median output loss of 0 percent. Clearly, countries that experienced a banking crisis suffered more than those which did not.

In contrast, fiscal costs are larger in developing and emerging economies, especially when expressed relative to financial system assets instead of GDP, to account for differences in the relative size of financial systems. ${ }^{20}$ Similarly,

${ }^{18}$ Data on reserve money come from IFS. For euro area countries, reserve money corresponds to the aggregation of currency issued and liabilities to depository corporations, divided by euro area GDP.

${ }^{19}$ By the same logic used to construct an alternative definition of a crisis based on declines in credit growth and real GDP, we define the end of a crisis as the year before both real GDP growth and real credit growth are positive for at least two consecutive years. In case the first two years record positive growth in real GDP and real credit, the crisis end date equals the starting date of the crisis. In computing end dates, we use bank credit to the private sector (in national currency) from IFS (line 22d). Bank credit series are deflated using CPI from WEO. GDP in constant prices (in national currency) also comes from the WEO. When credit data are not available, the end date are determined as the first year before GDP growth is positive for at least two years. In all cases, we truncate the duration of a crisis at five years, starting from the first year of the crisis.

${ }^{20}$ Financial system assets data are taken from the World Bank's Financial Structure database. They consist of domestic claims on the private sector by banks and nonbank financial institutions. They exclude foreign claims by banks and nonbank financial institutions. In the case of European Union countries, for which cross-border claims can be sizable, we instead use data from the European Central Bank (ECB) on the consolidated assets of financial institutions (excluding the Eurosystem and other national central banks), after 
liquidity pressures (as measured by peak liquidity support relative to deposits and foreign liabilities) and deterioration in loan quality (as measured by peak share of NPLs) tend to be more severe in developing and emerging economies than in advanced economies, although only the latter difference is statistically significant. Moreover, while increases in public debt during banking crises in emerging and developing economies are mostly due to fiscal outlays associated with financial sector intervention policies, in advanced economies such fiscal outlays constitute only a relatively small fraction of the overall increase in public debt. Discretionary fiscal policy and automatic stabilizers play a much more important role.

We noted in the previous section a marked difference among advanced and other economies in the use of macroeconomic policies. Similarly, increases in public debt and monetary expansion tend to be larger in advanced economies than in emerging and developing economies. These differences can help explain why fiscal costs associated with banking crises are lower in advanced economies. Note that the difference in monetary expansion between advanced economies vs. emerging and developing economies is now significant, consistent with what one would expect, unlike our earlier results based on a binary measure of monetary expansion. Emerging and developing economies face capital outflows and large currency depreciations upon which they respond by tightening monetary policy.

The greater reliance on macroeconomic tools may also explain why crises tend to last longer in advanced economies, with the caveat that a larger demand shock affecting advanced economies could also lengthen crisis duration. If macroeconomic policies are used to avoid a sharp contraction in economic activity, this may discourage more active bank restructuring that would allow banks to recover more quickly and renew lending, with the risk of prolonging the crisis and depressing growth for a prolonged period of time (see also Claessens and others, 2011).

These median values, however, mask the wide cross-country variation in the costs associated with banking crises. Figure 7 reports the 10 costliest crises in terms of fiscal costs, increases in public debt, and output losses. Along all three dimensions, recent and ongoing crises feature among the 10 costliest crises since the 1970s. In terms of fiscal costs, the still ongoing banking crises in Iceland and Ireland already rank among the 10 costliest crises. Fiscal costs have reached very high levels in Iceland and Ireland in part because of the relatively large size of the financial systems in these economies, amounting to multiples of GDP.

Iceland and Ireland also feature among the 10 costliest banking crises in terms of overall increase in public debt, with public debt in both cases increasing by more than 70 percent of GDP within four years. In terms of output losses, the ongoing crises in Ireland and Latvia are among the

netting out the aggregated balance sheet positions between financial institutions. Moreover, in the case of Iceland where cross-border claims are also sizable we use the assets of monetary and other financial institutions obtained from its national central bank. 
Figure 7. Costliest Banking Crises Since 1970

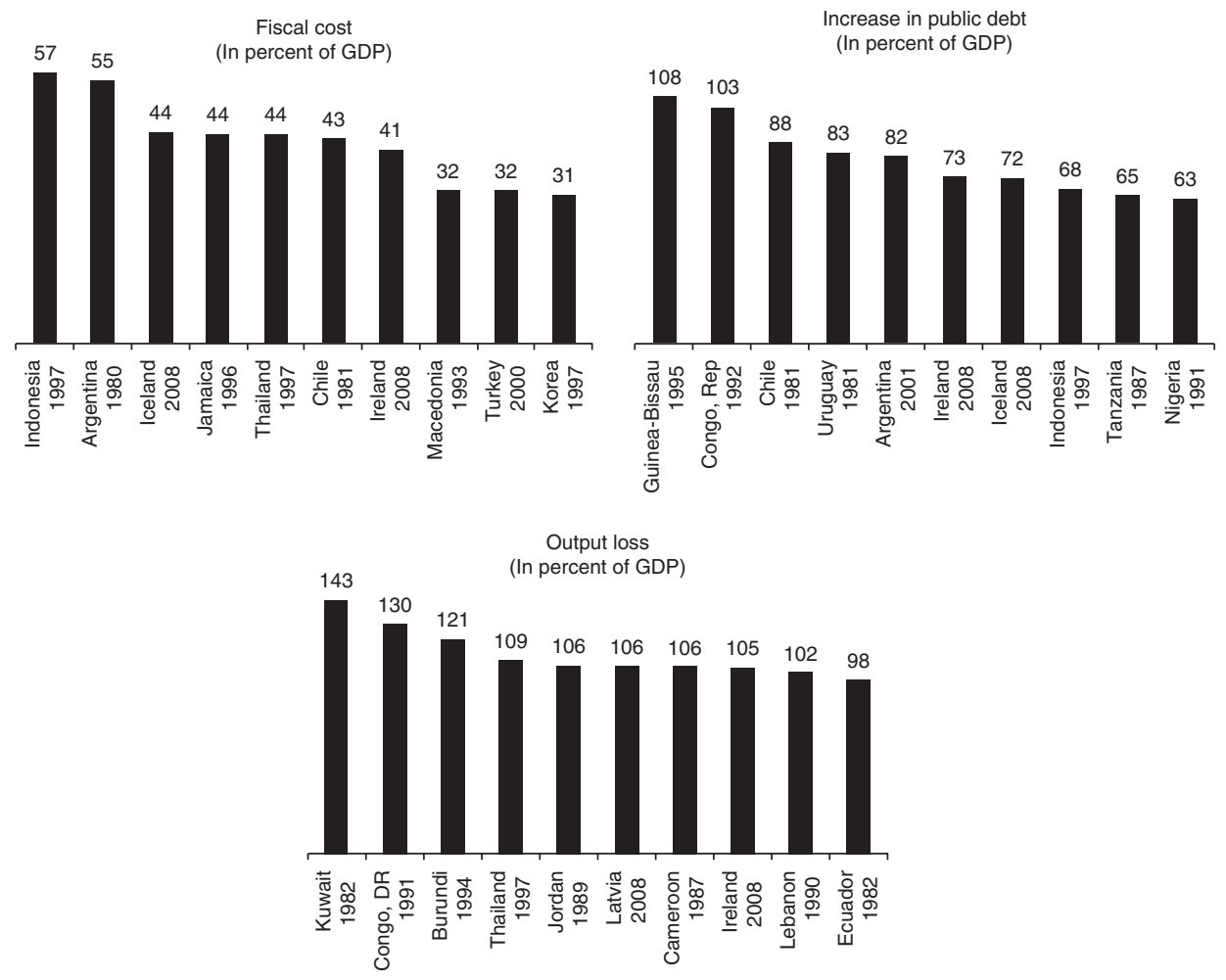

Source: Authors' calculations.

10 costliest banking crises since the 1970s, with output losses exceeding 100 percent in both cases. Ireland holds the undesirable position of being the only country currently undergoing a banking crisis that features among the top-10 of costliest banking crises along all three dimensions, making it the costliest banking crisis in advanced economies since at least the Great Depression. And the crisis in Ireland is still ongoing.

The size of the financial sector is an important driver of fiscal costs. Figure 8 shows a comparison between the median fiscal costs in emerging markets and advanced economies in our data, with fiscal costs expressed either in percent of GDP or in percent of financial system assets. For brevity, we only show the median value for emerging economies. For the median emerging market economy, fiscal costs double in magnitude when they are expressed in terms of financial system assets, highlighting the relatively low level of financial development in these economies. For advanced economies, Iceland, Ireland, and Israel stand out when fiscal costs are expressed relative to GDP, with Iceland being the costliest crisis in terms of fiscal costs to GDP at 44.2 percent of GDP. However, given the relatively large banking systems in Iceland and Ireland, fiscal costs are significantly lower in these countries 
Figure 8. Fiscal Costs Relative to GDP and Financial System Assets

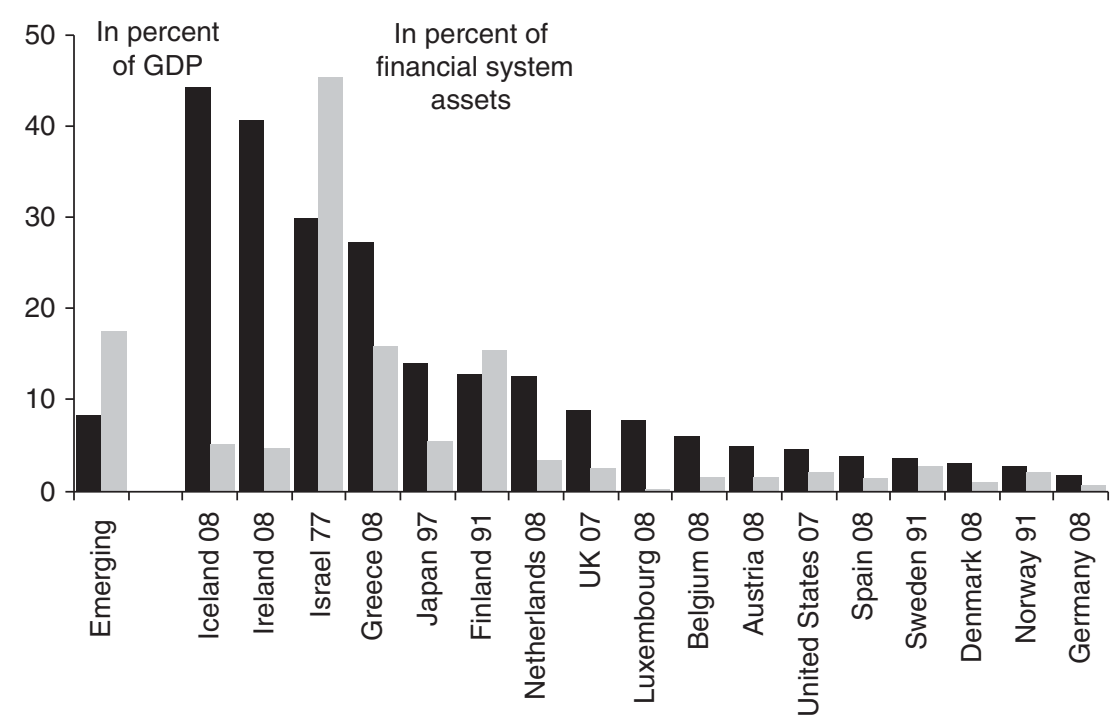

Source: Authors' calculations.

when expressed relative to financial system assets. When normalized by financial system assets, the highest fiscal outlays took place during Israel's banking crisis of 1977.

Fiscal costs consist primarily of bank recapitalizations and asset purchases. Table A2 shows the breakdown of fiscal costs for the recent crisis episodes, as well as detailed information on asset guarantees. The median fiscal cost for the recent episodes, excluding borderline cases, is 4.7 percent of GDP (2.8 percent with borderline episodes). Since most countries suffering a banking crisis since 2007 are advanced economies, the median fiscal cost is similar to that shown in Table 4 for advanced economies. This number, however, is about half of that for crises in emerging and developing economies. One explanation is that this time not all costs are born in the conventional way, that is, through a comprehensive restructuring of the banking system. Reliance on loose monetary policy can be seen as an alternative recapitalization of highly leveraged sectors, including financial institutions, although at a slower pace than through direct equity injections into financial institutions. Indeed, as shown in Table 5, the market valuation of financial institutions (as of end-2010) indicated in many cases still a sizable gap between the market and book value of banks. ${ }^{21}$ While overshooting in stock prices may be partly driving these gaps, they can also

\footnotetext{
${ }^{21}$ For a comparison between the recent crisis in the United States and the Euro zone see the working paper version (Laeven and Valencia, 2012).
} 
Table 5. Comparison of Market and Accounting Values of Bank Equity, end-2010

\begin{tabular}{|c|c|c|}
\hline \multirow[b]{2}{*}{ Country } & \multicolumn{2}{|c|}{ Difference between Market and Book Value of Distressed Banks ${ }^{1}$} \\
\hline & In percent of GDP & In percent of total banking assets \\
\hline Austria & 4.7 & 2.9 \\
\hline Belgium $^{2}$ & 6.7 & 2.4 \\
\hline Denmark & 0.8 & 0.4 \\
\hline France & 5.9 & 2.0 \\
\hline Germany & 1.6 & 1.2 \\
\hline Greece & 7.7 & 3.2 \\
\hline Ireland $^{2}$ & 6.1 & 3.0 \\
\hline Italy & 7.8 & 4.7 \\
\hline Kazakhstan ${ }^{2}$ & 0.4 & 0.8 \\
\hline Netherlands & 4.6 & 1.8 \\
\hline Portugal $^{2}$ & 3.3 & 2.3 \\
\hline Slovenia $^{2}$ & 0.8 & 2.4 \\
\hline Spain & 3.0 & 1.1 \\
\hline Sweden $^{2}$ & 0.2 & 0.1 \\
\hline Switzerland & 2.9 & 0.5 \\
\hline Ukraine $^{2}$ & 0.0 & 0.1 \\
\hline United Kingdom & 6.1 & 1.5 \\
\hline United States & 1.5 & 1.1 \\
\hline
\end{tabular}

Sources: Bankscope, Datastream, and authors' calculations.

${ }^{1}$ Country aggregate of the dollar value difference between the market and book values of bank equity for banks with a market-to-book value less than one. These gaps between market and book values of equity are expressed either relative to country GDP or total banking assets, where banking assets are computed by aggregating the consolidated balance sheets of individual banks in the sample at the country level.

${ }^{2}$ Country aggregate based on less than five banks.

be interpreted as suggesting that some banks may have sizable capital shortfalls. At the country level, the median gap between market and book values for banks with market-to-book values below one is about 3.3 percent of GDP.

Net fiscal costs, after asset recoveries, are significantly lower than gross outlays in some cases. For example, the Swiss authorities more than fully recovered the fiscal outlays associated with the convertible notes program offered in support of UBS. However, net fiscal outlays are not necessarily the right metric for assessing the success of a government program because taxpayer money was put at great risk in the process and because government interventions associated with market failures can be welfare enhancing even when outlays are positive.

\section{Currency and Sovereign Debt Crisis}

To compare outcomes under different types of financial crises, including banking, currency, and debt crises, we also report a list of currency and sovereign debt crisis dates. Our definition of a currency crisis builds on 
Frankel and Rose's (1996) approach. We define a currency crisis as a nominal depreciation of the currency vis-à-vis the U.S. dollar of at least 30 percent that is also at least 10 percentage points higher than the rate of depreciation in the year before. ${ }^{22}$ Using this approach, 211 currency crises can be identified during the period 1970-2011, of which 10 episodes occur during 2008-2011. ${ }^{23}$ It is important to recognize, however, that changes in these thresholds can lead to substantial changes in the list of currency crises. For instance, increasing the threshold to 40 percent lowers the number of episodes from 211 to 187 . However, our interest lies primarily in comparing output losses from banking crises to those from currency crises. Since for that purpose we compare medians across a large number of countries, our results are little affected when we vary the definition of currency crises.

We date episodes of sovereign debt default and restructuring by relying on information from Beim and Calomiris (2001), World Bank (2002), Sturzenegger and Zettelmeyer (2006), IMF Staff reports, and reports from rating agencies. The information compiled includes the year of sovereign default to private creditors and the year of debt rescheduling. Using this approach, we identify 66 episodes of sovereign debt crisis and debt restructuring during the period 1970-2011, of which three episodes during 2008-2011. Greece restructured its public debt in the first half of 2012, which yields one additional sovereign debt crisis case for the year 2012.

\section{Occurrence of Twin and Triplet Crises}

Banking crises frequently occur together with currency or sovereign debt crises. Figure 9 reports the frequency with which simultaneous crises occur, including twin crises (the simultaneous occurrence of banking and currency, currency and sovereign debt, or banking and sovereign debt crises) or triplet crises (the simultaneous occurrence of banking, currency, and sovereign debt crises). ${ }^{24}$ Triplet crises appear to be quite rare (we count only 10 such cases). Among twin crises, those associated with currency crises (either together with banking or sovereign debt crises) are most common, while those involving both banks and sovereign debt are least common.

\footnotetext{
${ }^{22} \mathrm{We}$ compute exchange rate depreciation as the percent change of the end-of-period official nominal bilateral dollar exchange rate from the World Economic Outlook (WEO) database of the IMF. For countries that meet the currency crisis criteria for several continuous years, we use the first year of each five-year window to identify the crisis. While our approach resembles that of Frankel and Rose (1996), our thresholds are not identical to theirs.

${ }^{23} \mathrm{We}$ exclude from the list currency crises that occur early in the process of transition toward market economies.

${ }^{24} \mathrm{We}$ define a twin crisis in year $t$ as a banking crisis in year $t$, combined with a currency (sovereign debt) crisis during the period $[T-1, T+1]$, and we define a triple crisis in year $t$ as a banking crisis in year $T$, combined with a currency crisis during the period $[T-1, T+1]$ and a sovereign debt crisis during the period $[T-1, T+1]$. Identifying the overlap between banking (currency) and sovereign crises follows the same approach, with $T$ the year of a banking (currency) crisis.
} 
Figure 9. Simultaneous Crises

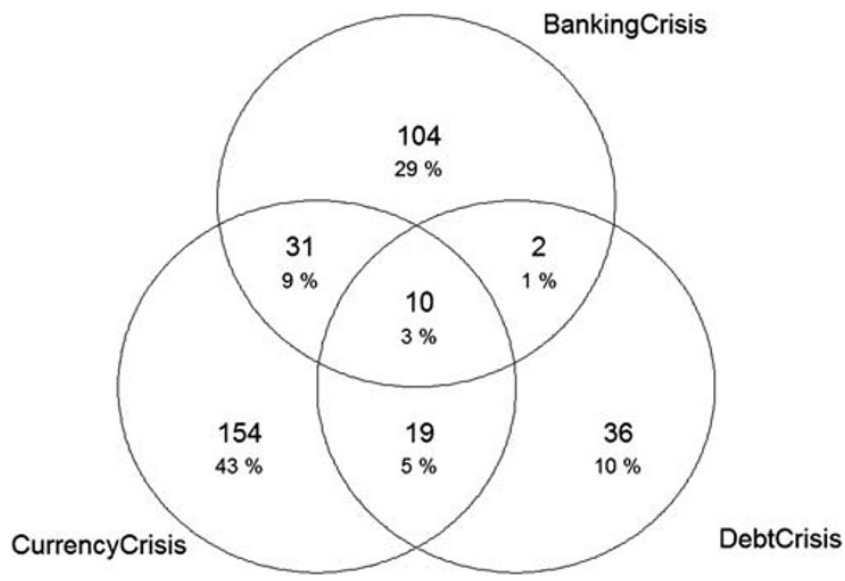

Source: Authors' calculations.

Note: Figure indicates the frequency of (simultaneous) banking, currency, and debt crises, including the total number and fraction (in percentage) of such crises.

\section{Sequencing of Financial Crises}

Numerous studies have examined the causes of different types of crises as well as the sequencing of crises to conclude that it is common for banking crises to precede currency and sovereign debt crises (for example, Kaminsky and Reinhart, 1999; Fratzscher, Mehl, and Vansteenkiste, 2011; Reinhart and Rogoff, 2011; Gourinchas and Obstfeld, 2012). Figure 10 corroborates this pattern in our data by showing the frequency of currency and sovereign debt crises (relative to the total number of banking crises) that take place in the same country as the banking crises over the period $T-3$ to $T+3$, where $T$ is the starting year of the banking crisis. We find that currency crises and especially sovereign debt crises tend to follow banking crises. While 16 percent of banking crises are preceded by a currency crisis in the same country within three years prior to the starting year of the banking crisis, 21 percent of banking crises are followed by a currency crisis within three years following the starting year of the banking crisis. The difference is starker for sovereign debt crises. Only 1 percent of banking crises in our sample are preceded by a sovereign debt crisis within three years prior to the start of the banking crisis, whereas 5 percent of banking crises are followed by a sovereign debt crisis within three years of the onset of the banking crisis.

\section{Output Losses across Different Types of Financial Crises}

In computing output losses for currency and debt crises, we follow the same methodology we use for banking crises. Table 6 shows the median output losses for banking, currency, and debt crises. 
Figure 10. Timing of Currency and Sovereign Debt Crises Relative to Banking Crises (In percent of the number of banking crises)

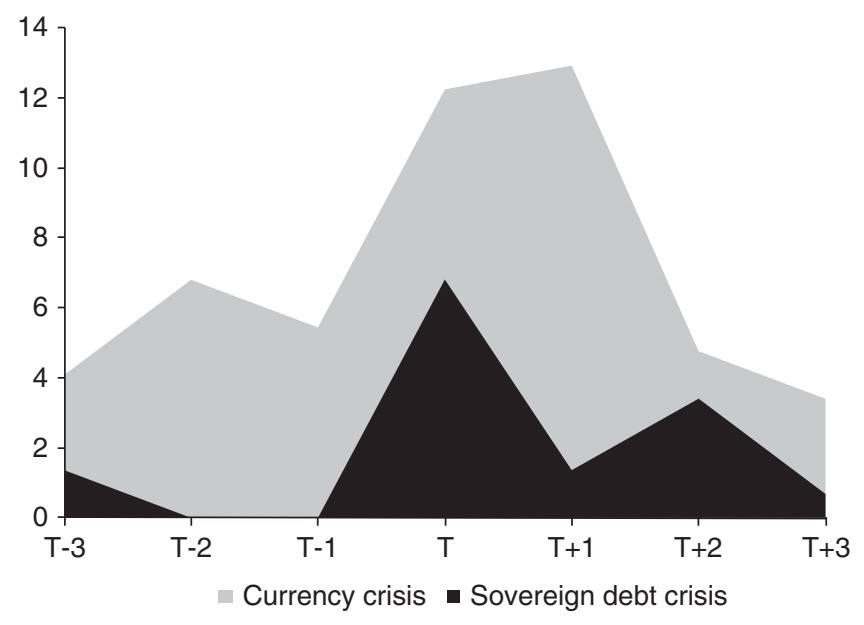

Source: Authors' calculations.

Note: $T$ denotes the starting year of the banking crisis.

Table 6. Comparison of Output Losses Across Types of Crises

\begin{tabular}{|c|c|c|}
\hline Type of Crisis & $\begin{array}{l}\text { Median Output } \\
\text { Loss (Percent } \\
\text { of Trend GDP) }\end{array}$ & $\begin{array}{l}\text { Null Hypothesis of Median } \\
\text { Test between Groups } \\
\text { (Pearson Chi-squared Test) }^{1}\end{array}$ \\
\hline Banking & 19.74 & - \\
\hline Currency & 3.04 & Banking $=$ Currency: $4.86^{* *}$ \\
\hline Debt & 40.38 & $\begin{array}{l}\text { Banking }=\text { Debt: } 2.10 \\
\text { Currency }=\text { Debt: } 10.28 * * *\end{array}$ \\
\hline Twin: Banking\&Currency & 18.83 & $\begin{array}{l}\text { Banking }=\text { Banking\&Currency: } 0.00 \\
\text { Currency = Banking\&Currency: } 5.98^{* *} \\
\text { Debt }=\text { Banking\&Currency: } 0.78\end{array}$ \\
\hline Twin: Currency\&Debt & 61.19 & $\begin{array}{l}\text { Banking = Currency\&Debt: } 7.96 * * * \\
\text { Currency = Currency\&Debt: } 10.08 * * * \\
\text { Debt }=\text { Currency\&Debt: } 2.03 \\
\text { Banking\&Currency = Currency\&Debt: } 7.58 * * *\end{array}$ \\
\hline
\end{tabular}

Source: Authors' calculations.

${ }^{1}$ Median output losses are equal across types of crises. Significance level: *10 percent, **5 percent, $* * * 1$ percent. Insufficient observations to compare output losses in triple crises and banking\&debt twin crises.

The evidence reported in Table 6 suggests that the output losses from a sovereign debt crisis are larger than those of a banking crisis, but the difference is not statistically significant. However, both banking and sovereign debt crises are associated with larger output losses than those in currency crises, and this difference is statistically significant. Moreover, a currency 
crisis combined with a debt crisis on average generates much worse output losses than a banking crisis alone or than a banking crisis combined with a currency crisis.

\section{Conclusions}

This paper provides a comprehensive database on systemic banking crises during the period 1970-2011. We propose a new methodology to date banking crisis episodes that is based on a combination of financial distress indicators and policy measures, and that can be consistently applied across countries and over time. We also perform several robustness checks to assess the sensitivity of our dating methodology to modifications in the variables or thresholds employed to date crises.

Together with these dates, we also report detailed information on policy responses associated with these banking crises. We use the data to highlight some patterns between these policy responses and the economic costs of crises. First, while traditionally costly banking crises were associated with emerging economies, more recent cases also involve advanced economies. This raises the question whether there has been any systematic change (such as financial deregulation or financial innovation) that has led to increased fragility of banking systems in advanced economies that are otherwise generally perceived to enjoy deeper financial markets and higher quality institutions. Second, while macroeconomic policies have been used aggressively in advanced economy crises, actual bank restructuring is in those cases relatively slow. This raises questions about the pace of recovery and the optimal policy mix in resolving financial crises in advanced economies. Moreover, it raises the question whether the availability and space to conduct macro policies reduces incentives for intrusive financial restructuring.

To contrast the output losses associated with banking crises with those of other types of financial crises, we also report a comprehensive list of currency and sovereign crisis dates. We find that output losses around sovereign crises are larger than those around banking crises, and that these in turn are larger than those around currency crises.

Taken together, the data indicate potentially important linkages between the economic consequences of banking crises and policy responses to resolve them. More research is needed to better understand the tradeoffs involved and to establish causality. It is our hope that the comprehensive nature of our crisis database, including the detailed information on policy responses associated with banking crises, will encourage such research and improve our understanding of the causes and consequences of banking crises, and how best to resolve them. 
Table A1. Banking Crises Dates and Costs, 1970-2011

\begin{tabular}{|c|c|c|c|c|c|c|c|c|c|c|}
\hline Country & Start & End & $\begin{array}{l}\text { Output } \\
\text { Loss }^{1}\end{array}$ & $\begin{array}{l}\text { Fiscal } \\
\text { Costs }^{2}\end{array}$ & $\begin{array}{c}\text { Peak } \\
\text { Liquidity }^{3}\end{array}$ & $\begin{array}{l}\text { Liquidity } \\
\text { Support }^{3}\end{array}$ & $\begin{array}{c}\text { Peak } \\
\text { NPLs }^{4}\end{array}$ & $\begin{array}{l}\text { Increase } \\
\text { in Public } \\
\text { Debt }^{5}\end{array}$ & $\begin{array}{l}\text { Monetary } \\
\text { Expansion }\end{array}$ & $\begin{array}{l}\text { Credit } \\
\text { Boom }^{7}\end{array}$ \\
\hline Albania $^{11}$ & 1994 & 1994 & - & - & 7.6 & - & 26.8 & - & - & - \\
\hline Algeria & 1990 & $1994^{9}$ & 41.4 & - & 37.6 & 29.9 & 30.0 & 19.1 & -4.7 & 0 \\
\hline Argentina & 1980 & $1982^{8}$ & 58.2 & 55.1 & 64.6 & 62.2 & 9.0 & 33.1 & 10.6 & 1 \\
\hline Argentina & 1989 & 1991 & 12.6 & 6.0 & 151.6 & 135.7 & 27.0 & -21.3 & 10.0 & 0 \\
\hline Argentina & 2001 & 2003 & 70.9 & 9.6 & 22.9 & 22.6 & 20.1 & 81.9 & 8.2 & 0 \\
\hline Armenia $^{4}$ & 1994 & $1994^{8}$ & - & - & 41.4 & 23.0 & - & - & - & 0 \\
\hline Austria & 2008 & - & 13.8 & 4.9 & 11.7 & 7.7 & 2.8 & 14.8 & 8.3 & 0 \\
\hline Azerbaijan $^{11}$ & 1995 & $1995^{8}$ & - & - & 127.6 & 84.5 & - & 0.9 & - & - \\
\hline Bangladesh & 1987 & 1987 & 0.0 & - & 26.0 & 2.8 & 20.0 & 3.5 & 1.4 & 0 \\
\hline Belarus $^{11}$ & 1995 & 1995 & - & - & 35.8 & - & - & -16.5 & - & 0 \\
\hline Belgium & 2008 & - & 19.1 & 6.0 & 19.7 & 14.1 & 3.1 & 18.7 & 8.3 & 1 \\
\hline Benin & 1988 & $1992^{9}$ & 14.9 & 17.0 & 99.6 & 48.6 & 80.0 & 5.7 & 13.0 & 1 \\
\hline Bolivia & 1994 & 1994 & 0.0 & 6.0 & 31.9 & 12.9 & 6.2 & -19.2 & 1.6 & 1 \\
\hline $\begin{array}{l}\text { Bosnia and } \\
\text { Herzegovina }^{11}\end{array}$ & 1992 & $1996^{9}$ & - & - & - & - & - & - & - & 0 \\
\hline Brazil $^{10}$ & 1990 & $1994^{9}$ & 62.3 & 0.0 & 11.3 & 10.7 & - & -22.6 & 7.7 & 1 \\
\hline Brazil & 1994 & 1998 & 0.0 & 13.2 & 20.1 & 17.6 & 16.0 & -33.8 & -4.3 & 1 \\
\hline Bulgaria & 1996 & 1997 & 63.1 & 14.0 & 17.3 & 9.9 & 75.0 & -30.1 & -2.2 & 0 \\
\hline Burkina Faso & 1990 & 1994 & - & - & 9.4 & 4.5 & 16.0 & 8.9 & 2.8 & 0 \\
\hline Burundi & 1994 & $1998^{9}$ & 121.2 & - & 23.4 & 18.3 & 25.0 & 10.9 & 2.6 & 0 \\
\hline Cameroon & 1987 & $1991^{9}$ & 105.5 & - & 59.1 & 40.9 & 65.0 & 18.0 & 1.0 & 0 \\
\hline Cameroon & 1995 & 1997 & 8.1 & - & 12.3 & 6.2 & 30.0 & -1.1 & 0.4 & 0 \\
\hline
\end{tabular}




\begin{tabular}{|c|c|c|c|c|c|c|c|c|c|c|}
\hline Cape Verde & 1993 & 1993 & 0.0 & - & 4.0 & - & 30.0 & 18.2 & -40.6 & 0 \\
\hline Central African Rep & 1976 & 1976 & 0.0 & - & 90.8 & 10.5 & - & -4.8 & 2.5 & 1 \\
\hline Central African Rep & 1995 & 1996 & 1.6 & - & 24.8 & 20.9 & 40.0 & -16.3 & 0.7 & - \\
\hline Chad & 1983 & 1983 & 0.0 & - & 199.3 & 41.3 & - & -7.2 & -0.3 & 0 \\
\hline Chad & 1992 & $1996^{9}$ & 0.0 & - & 120.9 & 41.4 & 35.0 & 27.1 & -0.8 & - \\
\hline Chile & 1976 & 1976 & 19.9 & - & 32.2 & 23.6 & - & -69.5 & 1.6 & 0 \\
\hline Chile & 1981 & $1985^{9}$ & 8.6 & 42.9 & 61.2 & 52.7 & 35.6 & 87.9 & 0.5 & 1 \\
\hline China, Mainland & 1998 & 1998 & 19.5 & 18.0 & 62.0 & 7.2 & 20.0 & 11.2 & 0.0 & 0 \\
\hline Colombia & 1982 & 1982 & 47.0 & 5.0 & 21.1 & 7.7 & 4.1 & 16.6 & -0.8 & 1 \\
\hline Colombia & 1998 & 2000 & 43.9 & 6.3 & 5.1 & 4.3 & 14.0 & 15.4 & 0.5 & 0 \\
\hline Congo, Dem Rep & 1983 & 1983 & 1.4 & - & 20.0 & 18.9 & - & 39.5 & - & 0 \\
\hline Congo, Dem Rep & 1991 & $1994^{9}$ & 129.5 & - & 44.7 & 30.2 & - & 42.2 & - & 0 \\
\hline Congo, Dem Rep & 1994 & $1998^{9}$ & 79.0 & - & 77.3 & 77.1 & 75.0 & 39.3 & - & 0 \\
\hline Congo, Rep & 1992 & 1994 & 47.4 & - & 30.7 & 16.6 & - & 103.5 & 1.4 & 0 \\
\hline Costa Rica & 1987 & 1991 & 0.0 & - & 20.2 & 6.1 & - & -27.5 & 2.9 & 0 \\
\hline Costa Rica & 1994 & 1995 & 0.0 & - & 15.2 & 6.3 & 32.0 & 4.8 & 1.1 & 1 \\
\hline Cote d'Ivoire & 1988 & $1992^{9}$ & 44.8 & 25.0 & 76.9 & 22.5 & 50.0 & 13.6 & -3.3 & 0 \\
\hline Croatia $^{11}$ & 1998 & 1999 & - & 6.9 & 3.2 & 3.1 & 10.5 & 14.1 & 5.2 & 0 \\
\hline Czech Republic ${ }^{10,11}$ & 1996 & $2000^{9}$ & - & 6.8 & 12.7 & 4.2 & 18.0 & 1.8 & -1.3 & 0 \\
\hline Denmark & 2008 & - & 36.3 & 3.1 & 20.1 & 11.4 & 4.5 & 24.9 & 1.2 & 0 \\
\hline Djibouti & 1991 & $1995^{9}$ & 0.0 & - & 5.2 & 3.2 & - & - & - & - \\
\hline Dominican Rep & 2003 & 2004 & - & 22.0 & 43.4 & 38.1 & 9.0 & 16.5 & 6.7 & 1 \\
\hline Ecuador & 1982 & $1986^{9}$ & 98.2 & - & 146.7 & 100.0 & - & 24.4 & -1.7 & 0 \\
\hline Ecuador & 1998 & 2002 & 23.3 & 21.7 & 26.0 & 22.5 & 40.0 & 9.1 & -0.5 & 1 \\
\hline Egypt & 1980 & 1980 & 0.9 & - & 66.7 & 22.7 & - & -4.2 & -2.3 & 1 \\
\hline El Salvador & 1989 & 1990 & 0.0 & - & 51.6 & 11.5 & 37.0 & -29.6 & - & 1 \\
\hline Equatorial Guinea & 1983 & $1983^{8}$ & 0.0 & - & 75.8 & - & - & - & - & 0 \\
\hline Eritrea & 1993 & $1993^{8}$ & - & - & - & - & - & - & - & 0 \\
\hline Estonia $^{11}$ & 1992 & 1994 & - & 1.9 & 30.9 & - & 7.0 & - & - & 0 \\
\hline Finland & 1991 & 1995 & 67.3 & 12.8 & 12.0 & 5.5 & 13.0 & 43.6 & - & 1 \\
\hline France $^{10}$ & 2008 & - & 23.6 & 1.0 & 8.9 & 7.4 & 4.0 & 17.3 & 8.3 & 0 \\
\hline Georgia $^{11}$ & 1991 & $1995^{9}$ & - & - & - & - & 33.0 & - & - & 0 \\
\hline Germany & 2008 & - & 12.1 & 1.8 & 11.5 & 3.6 & 3.7 & 17.8 & 8.3 & 0 \\
\hline
\end{tabular}




\begin{tabular}{|c|c|c|c|c|c|c|c|c|c|c|}
\hline Country & Start & End & $\begin{array}{l}\text { Output } \\
\text { Loss }^{1}\end{array}$ & $\begin{array}{l}\text { Fiscal } \\
\text { Costs }^{2}\end{array}$ & $\begin{array}{c}\text { Peak } \\
\text { Liquidity }^{3}\end{array}$ & $\begin{array}{l}\text { Liquidity } \\
\text { Support }^{3}\end{array}$ & $\begin{array}{c}\text { Peak } \\
\text { NPLs }^{4}\end{array}$ & $\begin{array}{l}\text { Increase } \\
\text { in Public } \\
\mathrm{Debt}^{5}\end{array}$ & $\begin{array}{l}\text { Monetary } \\
\text { Expansion }\end{array}$ & $\begin{array}{l}\text { Credit } \\
\text { Boom }^{7}\end{array}$ \\
\hline Ghana & 1982 & 1983 & 14.1 & 6.0 & 0.2 & 0.1 & 35.0 & 15.5 & -0.5 & - \\
\hline Greece & 2008 & - & 43.1 & 27.3 & 44.3 & 42.3 & 14.7 & 44.5 & 8.3 & 1 \\
\hline Guinea & 1985 & $1985^{8}$ & 0.0 & 3.0 & - & - & - & - & - & 0 \\
\hline Guinea & 1993 & 1993 & 0.0 & - & 14.6 & 3.9 & 45.0 & 6.7 & - & - \\
\hline Guyana & 1993 & 1993 & 0.0 & - & 1.8 & 1.7 & - & -241.0 & -10.5 & 0 \\
\hline Haiti & 1994 & 1998 & 37.5 & - & 4.8 & - & - & -119.4 & -5.8 & 0 \\
\hline Hungary $^{11}$ & 1991 & $1995^{9}$ & - & 10.0 & 47.0 & 4.6 & 23.0 & 19.6 & 4.5 & 0 \\
\hline Hungary $^{10}$ & 2008 & - & 39.9 & 2.7 & 1.4 & 1.3 & 13.3 & -0.3 & -0.8 & 1 \\
\hline Iceland & 2008 & - & 41.9 & 44.2 & 21.2 & 16.8 & 61.2 & 72.2 & -2.3 & 1 \\
\hline India & 1993 & 1993 & 0.0 & - & 4.3 & 3.6 & 20.0 & -7.7 & 1.3 & 0 \\
\hline Indonesia & 1997 & $2001^{9}$ & 69.0 & 56.8 & 23.1 & 17.2 & 32.5 & 67.6 & 4.5 & 0 \\
\hline Ireland & 2008 & - & 105.3 & 40.7 & 20.0 & 16.3 & 12.9 & 72.8 & 8.3 & 1 \\
\hline Italy & 2008 & - & 33.2 & 0.3 & 7.7 & 5.7 & 11.0 & 8.6 & 8.3 & 0 \\
\hline Jamaica & 1996 & 1998 & 32.2 & 43.9 & 0.4 & 0.3 & 28.9 & 2.9 & 7.6 & 0 \\
\hline Japan & 1997 & $2001^{9}$ & 45.0 & 14.0 & 2.4 & 1.6 & 35.0 & 41.7 & 7.2 & 0 \\
\hline Jordan & 1989 & 1991 & 106.4 & 10.0 & 20.7 & 16.1 & - & -61.0 & 15.5 & 0 \\
\hline Kazakhstan $^{10}$ & 2008 & - & 0.0 & 3.7 & 5.5 & 5.0 & 31.9 & 9.1 & 3.3 & 0 \\
\hline Kenya & 1985 & 1985 & 23.7 & - & 2.0 & 1.9 & - & 11.0 & 0.5 & 0 \\
\hline Kenya & 1992 & 1994 & 50.3 & - & 25.2 & 24.3 & - & 12.1 & 7.4 & 0 \\
\hline Korea & 1997 & 1998 & 56.1 & 31.2 & 27.4 & 11.9 & 35.0 & 9.9 & -0.4 & 1 \\
\hline Kuwait & 1982 & 1985 & 143.4 & - & 9.6 & 2.9 & 40.0 & 16.2 & 2.5 & 0 \\
\hline Kyrgyz Rep ${ }^{11}$ & 1995 & $1999^{9}$ & - & - & 286.1 & 51.8 & 85.0 & 42.9 & - & 0 \\
\hline Latvia $^{11}$ & 1995 & 1996 & - & 3.0 & 9.2 & 5.5 & 20.0 & 0.4 & - & - \\
\hline Latvia & 2008 & - & 106.2 & 5.6 & 3.6 & 3.4 & 15.9 & 28.1 & -2.7 & 1 \\
\hline Lebanon & 1990 & 1993 & 102.2 & - & 4.4 & 2.8 & - & - & - & - \\
\hline Liberia & 1991 & $1995^{9}$ & - & - & 85.2 & 84.2 & - & - & - & - \\
\hline
\end{tabular}




\begin{tabular}{|c|c|c|c|c|c|c|c|c|c|c|}
\hline Lithuania $^{11}$ & 1995 & 1996 & - & 3.1 & 27.5 & 18.9 & 32.2 & 10.8 & - & 0 \\
\hline Luxembourg & 2008 & - & 36.4 & 7.7 & 14.7 & 4.1 & 1.3 & 14.6 & 8.3 & 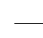 \\
\hline Macedonia, FYR ${ }^{11}$ & 1993 & 1995 & - & 32.0 & 22.3 & - & 70.0 & - & - & 0 \\
\hline Madagascar & 1988 & 1988 & 0.0 & - & 20.2 & 19.4 & 25.0 & -25.8 & 1.0 & 0 \\
\hline Malaysia & 1997 & 1999 & 31.4 & 16.4 & 9.7 & 8.8 & 30.0 & 0.2 & 4.0 & 1 \\
\hline Mali & 1987 & $1991^{9}$ & 0.0 & - & 50.5 & 14.8 & 75.0 & -11.3 & 1.7 & 0 \\
\hline Mauritania & 1984 & 1984 & 7.5 & 15.0 & 48.4 & 27.7 & 70.0 & - & 1.2 & 0 \\
\hline Mexico & 1981 & $1985^{9}$ & 26.6 & - & 5.3 & 2.6 & - & 22.6 & 5.0 & 0 \\
\hline Mexico & 1994 & 1996 & 10.2 & 19.3 & 16.8 & 15.8 & 18.9 & 16.4 & 0.4 & 1 \\
\hline Mongolia & 2008 & - & 0.0 & 4.2 & 10.5 & 9.4 & - & -5.0 & 3.0 & 0 \\
\hline Morocco & 1980 & $1984^{9}$ & 21.9 & - & 22.1 & 8.6 & - & 35.6 & -1.0 & 0 \\
\hline Mozambique & 1987 & $1991^{9}$ & 0.0 & - & 4.2 & 4.2 & - & 60.9 & -36.6 & 0 \\
\hline Nepal & 1988 & 1988 & 0.0 & - & 14.6 & 3.8 & 29.0 & 11.7 & 2.1 & 0 \\
\hline Netherlands & 2008 & - & 23.0 & 12.7 & 5.9 & 3.7 & 3.2 & 26.8 & 8.3 & 0 \\
\hline Nicaragua & 1990 & 1993 & 11.4 & - & 195.1 & 156.5 & 50.0 & -31.0 & - & 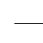 \\
\hline Nicaragua & 2000 & 2001 & 0.0 & 13.6 & 21.8 & 20.9 & 12.7 & 14.9 & 3.3 & 1 \\
\hline Niger & 1983 & 1985 & 97.2 & - & 45.6 & 14.1 & 50.0 & 25.9 & 3.5 & 1 \\
\hline Nigeria & 1991 & $1995^{9}$ & 0.0 & - & 6.6 & 5.4 & 77.0 & 63.3 & 7.2 & - \\
\hline Nigeria & 2009 & - & 0.0 & 11.8 & 25.3 & 11.7 & 30.1 & 7.7 & -0.5 & 0 \\
\hline Norway & 1991 & 1993 & 5.1 & 2.7 & 16.9 & 4.2 & 16.4 & 19.2 & 0.5 & 0 \\
\hline Panama & 1988 & 1989 & 85.0 & 12.9 & 3.6 & 3.2 & - & -2.6 & 0.1 & 0 \\
\hline Paraguay & 1995 & 1995 & 15.3 & 12.9 & 27.3 & 23.8 & 8.1 & -1.2 & 3.2 & 1 \\
\hline Peru & 1983 & $1983^{8}$ & 55.2 & - & 16.8 & 9.7 & - & 14.3 & 5.2 & 0 \\
\hline Philippines & 1983 & 1986 & 91.7 & 3.0 & 19.4 & 1.5 & 19.0 & 44.8 & 8.4 & 1 \\
\hline Philippines ${ }^{10}$ & 1997 & $2001^{9}$ & 0.0 & 13.2 & 1.4 & 0.7 & 20.0 & 10.4 & 0.8 & 1 \\
\hline Poland $^{11}$ & 1992 & 1994 & - & 3.5 & 45.9 & 8.7 & 24.0 & -21.6 & -0.7 & 0 \\
\hline Portugal $^{10}$ & 2008 & - & 36.8 & 0.0 & 18.0 & 16.7 & 7.3 & 33.6 & 8.3 & 0 \\
\hline Romania $^{11}$ & 1990 & $1992^{8}$ & - & 0.6 & 129.1 & - & 30.0 & - & 6.3 & 0 \\
\hline Russia $^{11}$ & 1998 & $1998^{8}$ & - & 0.1 & 23.7 & 21.1 & 40.0 & -7.1 & - & 0 \\
\hline Russia $^{10}$ & 2008 & - & 0.0 & 2.3 & 24.8 & 23.9 & 9.6 & 6.4 & 1.0 & 1 \\
\hline São Tomé \& Príncipe & 1992 & $1992^{8}$ & 1.9 & - & - & - & 90.0 & -706.3 & - & 0 \\
\hline Senegal & 1988 & 1991 & 5.6 & 17.0 & 74.7 & 6.6 & 50.0 & -14.2 & 2.0 & 0 \\
\hline Sierra Leone & 1990 & $1994^{9}$ & 34.5 & - & 0.0 & 0.0 & 45.0 & 62.9 & -0.8 & 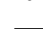 \\
\hline
\end{tabular}


Table A1 (continued)

\begin{tabular}{|c|c|c|c|c|c|c|c|c|c|c|}
\hline Country & Start & End & $\begin{array}{l}\text { Output } \\
\text { Loss }^{1}\end{array}$ & $\begin{array}{l}\text { Fiscal } \\
\text { Costs }^{2}\end{array}$ & $\begin{array}{c}\text { Peak } \\
\text { Liquidity }^{3}\end{array}$ & $\begin{array}{l}\text { Liquidity } \\
\text { Support }^{3}\end{array}$ & $\begin{array}{c}\text { Peak } \\
\text { NPLs }\end{array}$ & $\begin{array}{c}\text { Increase } \\
\text { in Public } \\
\text { Debt }^{5}\end{array}$ & $\begin{array}{l}\text { Monetary } \\
\text { Expansion }\end{array}$ & $\begin{array}{l}\text { Credit } \\
\text { Boom }^{7}\end{array}$ \\
\hline Slovak Rep & $1998^{11}$ & $2002^{9}$ & 44.2 & - & 13.0 & 4.8 & 35.0 & 15.4 & -1.0 & 1 \\
\hline Slovenia ${ }^{11}$ & 1992 & 1992 & - & 14.6 & 10.0 & - & 3.6 & - & - & 0 \\
\hline Slovenia ${ }^{10}$ & 2008 & - & 38.0 & 3.6 & 10.2 & 9.6 & 12.1 & 18.0 & 8.3 & 1 \\
\hline Spain & 1977 & $1981^{9}$ & 58.5 & 5.6 & 7.6 & 3.5 & 5.8 & 3.8 & - & 0 \\
\hline Spain & 2008 & - & 38.7 & 3.8 & 8.3 & 6.4 & 5.8 & 30.7 & 8.3 & 1 \\
\hline Sri Lanka & 1989 & 1991 & 19.6 & 5.0 & 8.0 & 2.0 & 35.0 & -5.5 & -1.0 & 0 \\
\hline Swaziland & 1995 & $1999^{9}$ & 45.7 & - & 3.6 & 3.2 & - & 2.5 & -1.0 & 0 \\
\hline Sweden & 1991 & 1995 & 31.6 & 3.6 & 3.1 & 0.2 & 13.0 & 36.2 & 5.1 & 1 \\
\hline Sweden ${ }^{10}$ & 2008 & - & 25.5 & 0.7 & 13.2 & 13.0 & 2.0 & 11.1 & 6.3 & 0 \\
\hline Switzerland ${ }^{10}$ & 2008 & - & 0.0 & 1.1 & 4.6 & 3.0 & 0.5 & -0.2 & 7.6 & 0 \\
\hline Tanzania & 1987 & 1988 & 0.0 & 10.0 & 100.9 & 97.6 & 70.0 & 64.6 & - & 0 \\
\hline Thailand & 1983 & 1983 & 24.8 & 0.7 & 8.5 & 2.0 & - & 15.7 & 0.3 & 0 \\
\hline Thailand & 1997 & 2000 & 109.3 & 43.8 & 5.1 & 4.4 & 33.0 & 42.1 & 3.9 & 1 \\
\hline Togo & 1993 & 1994 & 38.5 & - & 6.2 & 1.7 & - & 23.8 & -3.0 & 0 \\
\hline Tunisia & 1991 & 1991 & 1.3 & 3.0 & 31.5 & 15.1 & - & 4.2 & 0.1 & 1 \\
\hline Turkey & 1982 & 1984 & 35.0 & 2.5 & 71.7 & 29.3 & - & 12.3 & 2.4 & 1 \\
\hline Turkey & 2000 & 2001 & 37.0 & 32.0 & 20.5 & 15.2 & 27.6 & 15.3 & - & 1 \\
\hline Uganda & 1994 & 1994 & 0.0 & - & 7.6 & 3.9 & - & -26.9 & 0.6 & - \\
\hline Ukraine $^{11}$ & 1998 & 1999 & 0.0 & 0.0 & 19.1 & 3.3 & 62.4 & 6.0 & 3.4 & - \\
\hline Ukraine & 2008 & - & 0.0 & 4.5 & 30.1 & 9.2 & 15.5 & 28.9 & 1.7 & 1 \\
\hline United Kingdom & 2007 & - & 25.6 & 8.8 & 9.0 & 5.6 & 4.0 & 24.4 & 9.4 & 1 \\
\hline United States ${ }^{10}$ & 1988 & 1988 & 0.0 & 3.7 & 0.1 & 0.1 & 4.1 & 10.5 & -0.1 & 0 \\
\hline
\end{tabular}




\begin{tabular}{|c|c|c|c|c|c|c|c|c|c|c|}
\hline United States & 2007 & - & 30.6 & 4.5 & 4.7 & 4.7 & 5.0 & 23.6 & 7.9 & 0 \\
\hline Uruguay & 1981 & $1985^{9}$ & 38.1 & 31.2 & 24.6 & 18.5 & - & 83.3 & 3.2 & 1 \\
\hline Uruguay & 2002 & 2005 & 66.1 & 20.0 & 12.8 & 7.9 & 36.3 & 37.0 & 2.0 & 1 \\
\hline Venezuel & 1994 & $1998^{9}$ & 1.2 & 15.0 & 2.9 & 1.6 & 24.0 & -23.0 & 1.3 & 0 \\
\hline Vietnam & 1997 & 1997 & 0.0 & 10.0 & 64.9 & 24.8 & 35.0 & -52.7 & 4.9 & 0 \\
\hline Yemen & 1996 & 1996 & 12.2 & - & 0.8 & 0.7 & - & -56.7 & -12.4 & 0 \\
\hline Zambia & 1995 & 1998 & 31.6 & 1.4 & 27.9 & 24.9 & - & 36.2 & -1.7 & 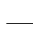 \\
\hline Zimbabwe & 1995 & $1999^{9}$ & 10.4 & - & 8.6 & 5.0 & - & 20.9 & 1.9 & 1 \\
\hline
\end{tabular}

Sources: WEO, IFS, IMF Staff reports, Laeven and Valencia (2008), and authors' calculations.

${ }^{1}$ In percent of GDP. Output losses are computed as the cumulative sum of the differences between actual and trend real GDP over the period [ $T$, $\left.T+3\right]$, expressed as a percentage of trend real GDP, with $T$ the starting year of the crisis.

${ }^{2}$ In percent of GDP. Fiscal costs are defined as the component of gross fiscal outlays related to the restructuring of the financial sector. They include fiscal costs associated with bank recapitalizations but exclude asset purchases and direct liquidity assistance from the Treasury.

${ }^{3}$ Liquidity is measured as the ratio of central bank claims on deposit money banks (line 12 in IFS) and liquidity support from the Treasury to total deposits and liabilities to nonresidents. Total deposits are computed as the sum of demand deposits (line 24), other deposits (line 25), and liabilities to nonresidents (line 26).

${ }^{4}$ In percent of total loans. NPLs data come from IMF Staff reports and Financial Soundness Indicators.

${ }^{5}$ In percent of GDP. The increase in public debt is measured over $[T-1, T+3]$, where $T$ is the starting year of the crisis. For the $2007-2009$ crises, it is computed as the difference between pre- and postcrisis debt projections.

${ }^{6}$ In percent of GDP. Monetary expansion is computed as the change in the monetary base between its peak during the crisis and its level one year prior to the crisis. Monetary expansion is the same for all euro area countries, measured at the euro area level to reflect the common monetary policy.

${ }^{7}$ As defined in Dell'Ariccia and others (2012).

${ }^{8}$ Credit data missing. For these countries, end dates are based on GDP growth only.

${ }^{9}$ We truncate the duration of crises at five years, starting with the first crisis year.

${ }^{10}$ Borderline cases.

${ }^{11}$ No output losses are reported for crises in transition economies that took place during the period of transition to market economies. Output losses are computed as the cumulative difference between actual and trend real GDP, expressed as a percentage of trend real GDP for the period [ $T$, $T+3$ ], where $T$ is the starting year of the crisis. Trend real GDP is computed by applying an HP filter $(\lambda=100)$ to the GDP series over [T-20, $T-1]$. 
Table A2. Direct Fiscal Outlays, Recoveries to Date, and Asset Guarantees, 2007-2011 (In percent of GDP)

\begin{tabular}{|c|c|c|c|c|c|}
\hline Country & Type of Outlay & Specific Fiscal Outlay & $\begin{array}{c}\text { Gross } \\
\text { Outlays }\end{array}$ & Recoveries $^{2}$ & $\begin{array}{l}\text { Net } \\
\text { Outlays }\end{array}$ \\
\hline \multirow[t]{4}{*}{ Austria } & Recapitalization & Capital Injection Program & 2.9 & & \\
\hline & Asset purchase & Impaired assets and liquidity & 2.0 & & \\
\hline & & Total fiscal outlays & 4.9 & & \\
\hline & Asset guarantee & Asset guarantee program & 0.6 & & \\
\hline \multirow[t]{7}{*}{ Belgium } & Recapitalization & Ethias, Fortis, KBC, and Dexia & 5.8 & & \\
\hline & Other & Capital for Fortis SPV & 0.2 & & \\
\hline & & Total fiscal outlays & 6.0 & & \\
\hline & Asset guarantee & Asset relief facility & 6.0 & & \\
\hline & & Fortis SPV & 1.3 & & \\
\hline & & Fortis portfolio & 0.4 & & \\
\hline & & Total asset guarantees & 7.7 & & \\
\hline \multirow[t]{4}{*}{ Denmark } & Recapitalization & Capital Assistance Program & 2.7 & & \\
\hline & & Capital injection in Fionia Bank & 0.1 & & \\
\hline & Other & Loan to Fionia Bank & 0.3 & & \\
\hline & & Total fiscal outlays & 3.1 & & \\
\hline \multirow[t]{4}{*}{ France } & Recapitalization & SPPE acquisition of subordinated bonds & 0.5 & & \\
\hline & & Second-stage recapitalization (BNP, SG, Dexia) & 0.5 & & \\
\hline & & Total fiscal outlays & 1.0 & & \\
\hline & Asset guarantee & Financial Security Assurance Inc. & 0.3 & & \\
\hline \multirow[t]{5}{*}{ Germany } & Recapitalization & Federal and state recapitalizations and guarantees for capital support & 1.7 & & \\
\hline & & Norddeutsche Landesbank Girozentrale & 0.1 & & \\
\hline & & Total fiscal outlays & 1.8 & & \\
\hline & Asset purchase & Asset purchase program & 11.1 & & \\
\hline & Asset guarantee & Bad Bank Act ${ }^{3}$ & 6.1 & & \\
\hline
\end{tabular}




\begin{tabular}{|c|c|c|c|c|c|}
\hline \multirow[t]{6}{*}{ Greece } & \multirow[t]{3}{*}{ Recapitalization } & Capital injection package I & \multicolumn{3}{|l|}{1.7} \\
\hline & & Agricultural Bank of Greece & \multicolumn{3}{|l|}{0.2} \\
\hline & & Capital injection package II & \multicolumn{3}{|l|}{0.5} \\
\hline & & 2012 Capital injection package III (IMF estimate) & \multicolumn{3}{|l|}{23.0} \\
\hline & Other & Liquidity & \multicolumn{3}{|l|}{1.9} \\
\hline & & Total fiscal outlays & \multicolumn{3}{|l|}{27.3} \\
\hline \multirow[t]{3}{*}{ Hungary } & Recapitalization & Capital injection in FHB (mortgage lender) & \multicolumn{3}{|l|}{0.1} \\
\hline & Other & FX loans to large banks & \multicolumn{3}{|l|}{2.6} \\
\hline & & Total fiscal outlays & 2.7 & 1.6 & 1.1 \\
\hline \multirow[t]{7}{*}{ Iceland } & \multirow[t]{4}{*}{ Recapitalization } & Securities lending & \multicolumn{3}{|l|}{6.2} \\
\hline & & Commercial banks recapitalizations & \multicolumn{3}{|l|}{14.7} \\
\hline & & Recapitalization of the House Financing Fund & \multicolumn{3}{|l|}{2.1} \\
\hline & & "Savings banks" & \multicolumn{3}{|l|}{1.3} \\
\hline & Other & Central bank recapitalization & \multicolumn{3}{|l|}{18.1} \\
\hline & & Called guarantees of the State Guarantee Fund & \multicolumn{3}{|l|}{1.8} \\
\hline & & Total fiscal outlays & 44.2 & 23.7 & 20.5 \\
\hline \multirow[t]{5}{*}{ Ireland } & Recapitalization & BoI, AIB, Anglo Irish, EBS, INBS & \multicolumn{3}{|l|}{29.5} \\
\hline & & Capital injections to meet PCAR stress test results & \multicolumn{3}{|l|}{11.2} \\
\hline & & Total fiscal outlays & \multicolumn{3}{|l|}{40.7} \\
\hline & Asset purchase & Assets purchased by NAMA & \multicolumn{3}{|l|}{20.3} \\
\hline & Asset guarantee & NAMA & \multicolumn{3}{|l|}{19.1} \\
\hline Italy & Recapitalization & Recapitalization scheme & \multicolumn{3}{|l|}{0.3} \\
\hline \multirow[t]{3}{*}{ Kazakhstan } & Recapitalization & BTA, Halyk, Alliance, and KKB & \multicolumn{3}{|l|}{2.4} \\
\hline & Other & Liquidity through deposits of the development agency & \multicolumn{3}{|l|}{1.3} \\
\hline & & Total fiscal outlays & \multicolumn{3}{|l|}{3.7} \\
\hline \multirow[t]{3}{*}{ Latvia } & \multirow{3}{*}{$\begin{array}{l}\text { Recapitalization } \\
\text { Other }\end{array}$} & Parex and MLBN & 3.1 & 0.8 & 2.3 \\
\hline & & Liquidity & 2.5 & & \\
\hline & & Total fiscal outlays & 5.6 & 0.8 & 4.8 \\
\hline
\end{tabular}




\begin{tabular}{|c|c|c|c|c|c|}
\hline Country & Type of Outlay & Specific Fiscal Outlay & $\begin{array}{l}\text { Gross } \\
\text { Outlays }\end{array}$ & Recoveries $^{2}$ & $\begin{array}{l}\text { Net } \\
\text { Outlays }\end{array}$ \\
\hline Luxembourg & Recapitalization & Fortis and Dexia & 7.7 & & \\
\hline Mongolia & Recapitalization & Recapitalization and restructuring costs & 4.2 & & \\
\hline \multirow{7}{*}{ the Netherlands } & Recapitalization & Fortis, ING, SNS, and AEGON & 6.6 & & \\
\hline & Other & Loans to Icesave and Icelandic deposit Insurance & 0.2 & & \\
\hline & & Loan to Fortis & 5.9 & & \\
\hline & & Total fiscal outlays & 12.7 & 7.1 & 5.6 \\
\hline & Asset guarantee & ABN AMRO/Fortis Mortgage portfolio & 6.0 & & \\
\hline & & ING Alt-A RMBS portfolio & 4.8 & & \\
\hline & & Total asset guarantees & 10.8 & & \\
\hline Nigeria & Recapitalization & Recapitalizations and purchase of bad assets & 11.8 & & \\
\hline \multirow[t]{4}{*}{ Russia } & Recapitalization & State Mortgage Agency, VTB, Rosselhozbank, Rosagroleasing, VEB & 1.0 & & \\
\hline & & Subordinated loans from VEB & 0.9 & & \\
\hline & & Liquidity through government deposits in commercial banks & 0.4 & & \\
\hline & & Total fiscal outlays & 2.3 & & \\
\hline \multirow[t]{3}{*}{ Slovenia } & Recapitalization & NLB and NKBM & 0.8 & & \\
\hline & Liquidity & Public sector deposits in banks (proceed from bond issue) & 2.8 & & \\
\hline & & Total fiscal outlays & 3.6 & & \\
\hline \multirow[t]{4}{*}{ Spain } & Recapitalization & Recapitalization of cajas and other banks ${ }^{4}$ & 2.0 & & \\
\hline & Asset purchase & Purchase of high-quality securities from credit institutions & 1.8 & & \\
\hline & & Total fiscal outlays & 3.8 & & \\
\hline & Asset guarantee & Asset protection scheme for BBK (takeover of Cajasol) & 0.0 & & \\
\hline
\end{tabular}


Sweden

Switzerland

Ukraine

United Kingdom

nited States

\section{Recapitalization}

Other

Recapitalization

Recapitalization

Recapitalization

Other

Asset guarantee
Recapitalization package

Initial contribution to stabilization fund

Total fiscal outlays

Mandatory convertible notes UBS

Public recapitalization program

RBS, Lloyds, LBG, and Northern Rock

Dunfermline Building Society takeover

Deposit compensation

Loans to Northern Rock and Bradford \& Bingley

Total fiscal outlays

Pool of RBS assets and CoCos

Recapitalization Capital Purchase Program (CPP)

AIG

Targeted Investment Program

Support to GMAC

Support to Fannie Mae and Freddie Mac

Other
Asset purchase

Automotive Industry Financial program

MBS purchase

Public-Private Investment Program

Total fiscal outlays

Asset guarantee

$\begin{array}{lll}1.5 & 1.5 & 0 \\ 0.5 & 0.1 & 0.4 \\ 0.3 & 0.3 & 0 \\ 0.1 & 0 & 0.1 \\ 1.2 & 0.2 & 1.0 \\ 0.5 & 0.3 & 0.2 \\ 0.3 & 0 & 0.3 \\ 0.1 & 0 & 0.1 \\ 4.5 & 2.4 & 2.1 \\ \text { small } & & \end{array}$

Sources: IMF staff reports and official websites.

${ }^{1}$ Gross fiscal costs and recoveries differ somewhat from those in the IMF's Fiscal Monitor (February 2012, Table 7, p. 23), partly reflecting the different time periods used. For Germany, the Fiscal Monitor figures include financial sector support measures taken by subnational governments. And for Greece, the Fiscal Monitor figures do not include the spring 2012 capital injection package.

${ }^{2}$ Includes repayments up to end-2011 of capital support as well as interest and fees generated from loans and guarantee programs for the cases where the data were available.

${ }^{3}$ Includes guarantees issued by the Stabilization Fund (items related to the Bad Bank Act and debt issued by financial institutions).

${ }^{4}$ Recapitalized banks include Catalunya Caixa, Unnim, España-Duero, Nova Caixa Galicia, Banco Financiero y de Ahorros, Banco Mare Nostrum, Banca Civica, Caja del Mediterraneo, and Banco de Valencia. 


\begin{tabular}{|c|c|c|c|c|c|}
\hline Country & $\begin{array}{l}\text { Liquidity Support } \\
\text { (percentage points } \\
\text { increase in central } \\
\text { bank claims on } \\
\text { financial institutions } \\
\text { over deposits and } \\
\text { foreign liabilities) } \\
\end{array}$ & $\begin{array}{l}\text { Gross Restructuring } \\
\text { Costs } \\
\text { (recapitalization and } \\
\text { other restructuring } \\
\text { costs, excluding } \\
\text { liquidity support, in } \\
\text { percent of GDP) }\end{array}$ & $\begin{array}{l}\text { Asset Purchases } \\
\text { and } \\
\text { Guarantees } \\
\text { (funded by } \\
\text { Treasury and } \\
\text { central bank, } \\
\text { in percent of } \\
\text { GDP) }\end{array}$ & $\begin{array}{l}\text { Guarantees on Bank Liabilities } \\
\text { (significant guarantees on bank } \\
\text { liabilities in addition to } \\
\text { increasing deposit insurance } \\
\text { ceilings) }\end{array}$ & $\begin{array}{l}\text { Significant Nationalizations } \\
\text { (state takes control over } \\
\text { institutions; year of } \\
\text { nationalization between } \\
\text { brackets) }\end{array}$ \\
\hline Austria & 8 & 4.9 & Guarantees: 0.6 & $\begin{array}{l}\text { Unlimited coverage to depositors } \\
\text { Bank and nonbank bond issues }\end{array}$ & $\begin{array}{l}\text { Hypo Group Alpe Adria, } \\
\text { Kommunalkredit (2009) }\end{array}$ \\
\hline Belgium & 14.1 & 6.0 & Guarantees: 7.7 & $\begin{array}{l}\text { DI raised from } € 20,000 \text { to } € 100,000 \\
\text { Deposit-like insurance instruments } \\
\text { Interbank loans and short-term } \\
\text { debt } \\
\text { Specific guarantees on Dexia }\end{array}$ & $\begin{array}{l}\text { Fortis (2008), Dexia Bank } \\
\quad \text { Belgium (2011) }\end{array}$ \\
\hline Denmark & 11.4 & 2.8 & & $\begin{array}{l}\text { Deposits and unsecured claims of } \\
\text { PCA banks }\end{array}$ & Fionia Bank (2009) \\
\hline France & 7.4 & 1.0 & Guarantees: 0.3 & $\begin{array}{l}\text { DI already higher than EU new } \\
\text { limit } \\
€ 360 \text { billion in guarantees for } \\
\text { refinancing credit institutions } \\
\text { Guarantee on } € 55 \text { billion of } \\
\text { Dexia's debt }\end{array}$ & \\
\hline
\end{tabular}


Greece $^{1}$

Hungary

Iceland

Ireland
Guarantees: 6.1 Unlimited coverage of household

(nases:

11.1

Interbank loans and bank debt (capped at $€ 400$ billion)

DI raised from $€ 20,000$ to $€ 100,000$

Funding guarantees up to $€ 15$ billion, expanded to $€ 15$ billion in 2011

Unlimited protection to depositors of small banks

Unlimited coverage to domestic deposits

\section{Guarantees: 19.1 Unlimited coverage to most} Purchases: liabilities of 10 banks

20.3

State guarantee for new bank liabilities

DI raised from T0.7 million to T5 Bank Turan Alem, Alliance Bank million (2009)

DI raised to $€ 50,000$

Guarantee on Parex syndicated

Hypo Real Estate (2009)

Kaupthing, Landsbanki, Glitnir, Straumur-Burdaras, SPRON and Sparisjódabankinn (all 2008)

Anglo Irish Bank (2009), EBS limited and Irish Nationwide Building Society (2010), Irish Life and Permanent (2011) loans 


\begin{tabular}{|c|c|c|c|c|c|}
\hline & Liquidity Support & $\begin{array}{l}\text { Gross Restructuring } \\
\text { Costs }\end{array}$ & $\begin{array}{l}\text { Asset Purchases } \\
\text { and } \\
\text { Guarantees }\end{array}$ & Guarantees on Bank Liabilities & Significant Nationalizations \\
\hline Country & $\begin{array}{l}\text { increase in central } \\
\text { bank claims on } \\
\text { financial institutions } \\
\text { over deposits and } \\
\text { foreign liabilities) }\end{array}$ & $\begin{array}{l}\text { (recapitalization and } \\
\text { other restructuring } \\
\text { costs, excluding } \\
\text { liquidity support, in } \\
\text { percent of GDP) }\end{array}$ & $\begin{array}{l}\text { (funded by } \\
\text { Treasury and } \\
\text { central bank, } \\
\text { in percent of } \\
\text { GDP) }\end{array}$ & $\begin{array}{l}\text { (significant guarantees on bank } \\
\text { liabilities in addition to } \\
\text { increasing deposit insurance } \\
\text { ceilings) }\end{array}$ & $\begin{array}{l}\text { (state takes control over } \\
\text { institutions; year of } \\
\text { nationalization between } \\
\text { brackets) }\end{array}$ \\
\hline
\end{tabular}

Luxembourg

Mongolia

the Netherlands

3.7

16.7

Portugal $^{2}$

4.1

4

Nigeria

1.7
DI raised from $€ 20,000$ to $€ 100,000$ Fortis and Dexia's subsidiaries (2008)

$€ 4.5$ billion guarantee on Dexia's debt

Unlimited coverage to all deposits Zoos Bank (2009)

Guarantees: 3.3 DI raised to $€ 100,000$

Interbank loans of solvent banks

Fortis bonds ( $€ 5$ billion) and ING

bonds ( $€ 10$ billion)

ABN-AMRO/Fortis (2008)

Purchases: 9.3 Guaranteed on all interbank transactions, foreign credit lines, and pension deposits

Afribank Plc, Bank PHB Plc, Spring Bank Plc (2011)

DI raised from $€ 25,000$ to $€ 100,000$

Debt securities issued by credit institutions ( $20 \%$ of GDP) 
Slovenia

Spain

Sweden
DI raised from $\mathrm{R} 400,000$ to

$$
\text { R700,000 }
$$

Interbank lending for qualifying banks

Unlimited protection for all deposits by individuals and small enterprises until end-2010, and capped at $€ 100,000$ thereafter

New debt issued by financial institutions until end-2010

Purchases: 1.8 DI raised from $€ 20,000$ to $€ 100,000$

Guarantees on new debt issued by financial institutions until end2010 (capped at $€ 200$ billion)

DI raised from SEK 250,000 to SEK 500,000

Medium-term debt of banks and mortgage institutions (up to SEK 1.5 trillion)

Purchases: 6.7 DI raised from SFr 30,000 to SFr 100,000

DI raised from UAH 50,000 to 150,000

Prominvest (2008), Nadra,

Inprom, Volodimrski, Dialog, Rodovid, Kiev, Ukrgaz (all 2009)

Purchases: 16.3 DI raised from $£ 35,000$ to 50,000 Northern Rock (2008); RBS 


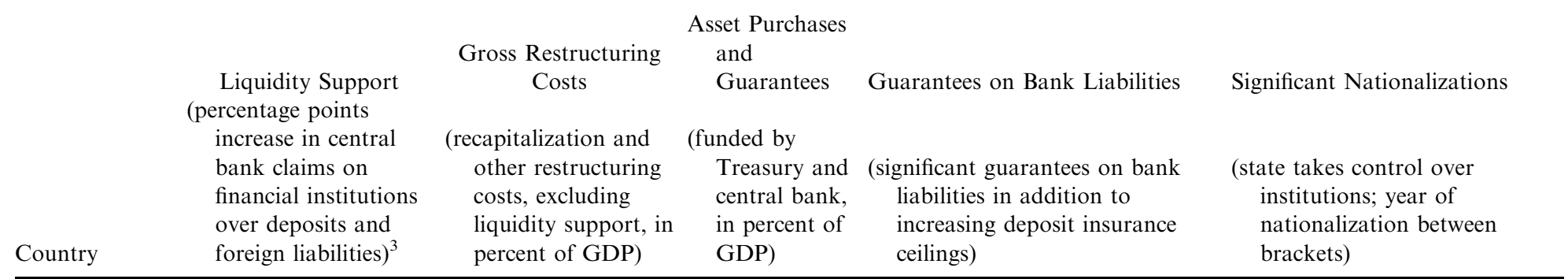

Guarantees: 14.5 Guarantee on short- to mediumterm debt (capped at $£ 250$ billion)

Blanket guarantee on Northern Rock and

Bradford \& Bingley wholesale deposits

United States 4.7
4.5
Purchases: 13.0 DI raised from $\$ 100,000$ to $\$ 250,000$

Money market funds (capped at $\$ 50$ billion)

Full guarantee on transaction deposits

Newly issued senior unsecured debt
Fannie Mae, Freddie Mac, AIG (all 2008).

\footnotetext{
Sources: IMF staff reports, official websites, and authors' calculations.

${ }^{1}$ Greece's fiscal cost includes the bank recapitalization funds for 23 percent of GDP included in the 2012 program. Since these funds will cover losses triggered by the debt exchange, we include them although they were not fully used as of May 2012.

${ }^{2}$ For Portugal, the funds allocated for bank restructuring purposes are not included because they have not been used yet and it is unclear how much and when they will be used.

${ }^{3}$ Includes liquidity support from the Treasury in the case of Austria, Denmark, Greece, Hungary, Kazakhstan, Latvia, the Netherlands, Russia, Slovenia, and the United Kingdom.
} 


\section{REFERENCES}

Abbas, S.Ali, Nazim Belhocine, Asmaa El Ganainy, and Mark Horton, 2010, "A Historical Public Debt Database," IMF Working Paper 10/245, (Washington: International Monetary Fund).

Ashcraft, Adam, 2005, "Are Banks Really Special? New Evidence from the FDIC-Induced Failure of Healthy Banks," American Economic Review, Vol. 95, No. 5, pp. 1712-30.

Beim, David, and Charles Calomiris, 2001, Emerging Financial Markets, Appendix to Chapter 1, (New York: McGraw-Hill/Irwin Publishers).

Bernanke, Ben, and Mark Gertler, 1987, "Banking and Macroeconomic Equilibrium," in New Approaches to Monetary Economics, ed. by W. Barnett and K. Singleton (New York: Cambridge University Press).

Caprio, Gerard, and Daniela Klingebiel, 1996, "Bank Insolvencies: Cross-Country Experience," Policy Research Working Paper No. 1620 (Washington: World Bank).

Caprio, Gerard, Daniela Klingebiel, Luc Laeven and Guillermo Noguera, 2005, "Appendix: Banking Crisis Database," in Systemic Financial Crises: Containment and Resolution, ed. by Patrick Honohan and Luc Laeven (Cambridge: Cambridge University Press), pp. 307-40.

Claessens, Stijn, others 2011, "Crisis Management and Resolution: Early Lessons from the Financial Crisis," IMF Staff Discussion Note 11/05, (Washington: International Monetary Fund).

Dell'Ariccia, Giovanni, Deniz Igan, Luc Laeven, and Hui Tong, 2012, "Policies for Macrofinancial Stability: How to Deal with Credit Booms," IMF Staff Discussion Note 12/06, (Washington: International Monetary Fund).

Frankel, Jeffrey, and Andrew Rose, 1996, "Currency Crashes in Emerging Markets: An Empirical Treatment," Journal of International Economics, Vol. 41, No. 3-4, pp. 351-66.

Fratzscher, Marcel, Arnaud Mehl, and Isabel Vansteenkiste, 2011, "130 Years of Fiscal Vulnerabilities and Currency Crashes in Advanced Economies," IMF Economic Review, Vol. 59, pp. 683-716.

Giannetti, Mariassunta, and Andrei Simonov, 2013, "On the Real Effects of Bank Bailouts: Micro Evidence from Japan," American Economic Journal: Macroeconomics, Vol. 5, No. 1, pp. 135-67.

Gourinchas, Pierre-Olivier, and Maurice Obstfeld, 2012, "Stories of the Twentieth Century for the Twenty-First," American Economic Journal: Macroeconomics, Vol. 4, No. 1, pp. 226-65.

Honohan, Patrick, and Luc Laeven, eds., 2005, Systemic Financial Crises: Containment and Resolution (Cambridge, UK: Cambridge University Press).

Kaminsky, Graciela, and Carmen Reinhart, 1999, "The Twin Crises: The Causes of Banking and Balance-of-Payments Problems," American Economic Review, Vol. 89, No. 3, pp. 473-500.

Kroszner, Randall, Luc Laeven, and Daniela Klingebiel, 2007, "Banking Crises, Financial Dependence, and Growth," Journal of Financial Economics, Vol. 84, No. 1, pp. 187-228.

Laeven, Luc, and Fabián Valencia, 2008, "Systemic Banking Crises: A New Database," IMF Working Paper 08/224, (Washington: International Monetary Fund). , 2010, "Resolution of Banking Crises: The Good, the Bad, and the Ugly," IMF Working Paper 10/44, (Washington: International Monetary Fund). 
, 2012, “Systemic Banking Crises: An Update," IMF Working Paper 12/163, (Washington: International Monetary Fund).

, 2013, "The Real Effects of Financial Sector Interventions during Crises," Journal of Money, Credit, and Banking, Vol. 45, No. 1, pp. 147-77.

Peek, Joe, and Erik Rosengren, 1997, “The International Transmission of Financial Shocks: The Case of Japan," American Economic Review, Vol. 87, No. 4, pp. 495-505.

Philippon, Thomas, and Philipp Schnabl, 2013, "Efficient Recapitalization," Journal of Finance, Vol. 68, No. 1, pp. 1-42.

Reinhart, Carmen, and Kenneth Rogoff, 2009, This Time is Different: Eight Centuries of Financial Folly (Princeton, New Jersey: Princeton University Press). 2011, "From Financial Crash to Debt Crisis," American Economic Review, Vol. 101, No. 5, pp. 1676-706.

Sandri, Damiano, and Fabián Valencia, Forthcoming, "Financial Crises and Recapitalizations," Journal of Money, Credit, and Banking.

Schularick, Moritz, and Alan M. Taylor, 2012, "Credit Booms Gone Bust: Monetary Policy, Leverage Cycles, and Financial Crises, 1870-2008," American Economic Review, Vol. 102, No. 2, pp. 1029-61.

Sturzenegger, Federico, and Jeromin Zettelmeyer, 2006, Debt Defaults and Lessons from a Decade of Crises (Cambridge: MIT Press).

Valencia, Fabián, Forthcoming, "Banks' Precautionary Capital and Credit Crunches," Macroeconomic Dynamics.

Van Den Heuvel, Skander, 2006, "The Bank Capital Channel of Monetary Policy," University of Pennsylvania unpublished manuscript.

World Bank, 2002, Global Development Finance, Appendix on Commercial Debt Restructuring, (Washington, DC: World Bank).

Supplementary information accompanies the paper on IMF Economic Review Website (www.palgrave-journals.com/imfer) 